\title{
งารสารวิศวกรSแศาสกร์
}

การพัฒนาระบบการสื่อสารของโครงการในงานวิศวกรรม งานจัดซื้อ จัดจ้าง และงานก่อสร้างในธุรกิจปิโตรเลียม และปิโตรเคมี

พูนศักดิ์ องค์วงศ์สกุล* และ สุทัศน์ รัตนเกื้อกังวาน

ภาควิชาวิศวกรรมอุตสาหการ คณะวิศวกรรมศาสตร์ จุฬำลงกรณ์มหาวิทยาลัย กรุงเทพฯ ประเทศไทย 10330 อีเมล์: poonsak.o@pttgcgroup.com*

บทคัดย่อ งานวิจัยฉบับนี้มีวัตถุประสงค์เพื่อพัฒนาระบบการสื่อสาร สำหรับใช้ในการบริหารโครงการในงานวิศวกรรม งาน จัดซื้อ จัดจ้าง และงานก่อสร้าง (โครงการอีพีซี) ของบริษัทกรณีศึกษาที่สามารถลดปัญหาเกี่ยวกับการไม่ได้รับข้อมูล ปัญหา ความไม่เข้าใจ และปัญหาการไม่ให้ความร่วมมือของพนักงานที่เกี่ยวข้อง สำหรับการดำเนินงานวิจัยนี้ได้มีการรวบรวม ปัญหาการสื่อสารที่เกิดขึ้นจากการบริหารงานโครงการอีพีซี 5 โครงการ เนื่องจากปัญหาการสื่อสารถือเป็นปัจจัยสำคัญที่ ก่อให้เกิดความเสี่ยงในงานโครงการ ดังนั้นงานวิจัยนี้ได้รวบรวมข้อมูลมาทำการจัดลำดับความสำคัญ และรุนแรงของปัญหา โดยการประยุกต์ใช้ทฤษฎีการประเมินความเสี่ยง (Risk Assessment) เมื่อได้ปัญหาที่มีคะแนนความเสี่ยงอยู่ในระดับสูงจึง นำมาวิเคราะห์ด้วยแผนภูมิก้างปลาเพื่อหาสาเหตุหลักโดยการระดมสมองจากผู้มีประสบการณ์ในงานโครงการ สำหรับ สาเหตุหลักของปัญหาได้ถูกนำเสนอแนวทางแก้ไขโดยการพัฒนาระบบการสื่อสาร จากผลของการวิจัยพบว่าระบบการ สื่อสารที่พัฒนาขึ้นมีประสิทธิภาพถึง 87 เปอร์เซ็นต์ โดยทำให้ปัญหาการสื่อสารส่วนใหญ่ของโครงการอีพีซีทดสอบที่มีระดับ คะแนนความเสี่ยงสูงมีแนวโน้มลดลงจนอยู่ในระดับที่สามารถยอมรับได้ ทั้งนี้ได้ทำการวิเคราะห์จากผลกระทบของอัตราการ เกิดปัญหา หรือความถี่ในการเกิดปัญหาการสื่อสารนั้นมีค่าลดลง โดยคงเหลือเพียง 2 ปัญหาเท่านั้นที่พบว่าคะแนนความ เสี่ยงยังคงอยู่ในระดับสูง

คำสืบค้น : ระบบการสื่อสาร, ปัญหาการสื่อสาร, โครงการอีพีซี

วารสารวิศวกรรมศาสตร์ (ISSN: 1906-3636) ปีที่ 4 ฉบับที่ 4

วันที่สง 26 กุมภาพันธ์ 2556

วันที่ตอบรับ 17 พฤษภาคม 2556

วันที่ตีพิมพ์ 20 กันยายน 2556

Online at http://www.ej.eng.chula.ac.th/

DOI:10.4186/ejth.2012.4.4.37 


\title{
งารสารวิศวกรSแศาสกร์
}

\section{Communication System Development of EPC Project in Petroleum and Petrochemical Business}

\author{
Poonsak Ongwongsakul ${ }^{\star}$ and Suthas Ratanakuakangwan
}

Department of Industrial Engineering, Faculty of Engineering, Chulalongkorn University, Bangkok 10330, Thailand

E-mail: poonsak.o@pttgcgroup.com*

Abstract. The objective of this research is to develop a communication system for Engineering, Procurement and Construction Management (EPC) Projects through some case study projects of EPC Company in order to reduce a problem of information delivery failed, understandability problem of accurate communication and poor collaboration from relevant people. The information on communication problems of five EPC projects had been discovering into this research. The communication problems were prioritized and classified based on a principle of Risk Assessment. The high range of risk problems had been investigated and analysed by many experienced engineers through Cause and Effect Diagram to identify the root causes. The root causes of problems were studied and applied in developing and improving a communication system. The result of this research was found that the improved communication system is able to support and assist the real EPC case study project. An efficiency of more than $87 \%$ can be achieved by using this improved communication system because those current communication problems could be relieved to acceptable level. The result can be seen by the rate and frequency of communication problems was minimized; however, only two communication problems remain the same and should probably be investigated more.

Keywords: Communication system, communication problems, EPC project.

Engineering Journal (ISSN: 1906-3636) Volume 4 Issue 4

Received 26 February 2013

Accepted 17 May 2013

Published 20 September 2013

Online at http://www.ej.eng.chula.ac.th/

DOI:10.4186/ejth.2012.4.4.37 


\section{1. บทนำ}

ปัญหาการติดต่อสื่อสารภายในองค์กร หรือโครงการต่างๆ ในปัจจุบันยังคงเป็นสาเหตุสำคัญที่มีผลต่อความสำเร็จของ องค์กรหรือโครงการ โดยเฉพาะองค์กรที่มีลักษณะการทำงานแบบโครงการที่อาจพบการเปลี่ยนแปลงลักษณะงานอยู่ ตลอดเวลา ถ้าหากไม่มีระบบการติดต่อสื่อสารที่ใช้ในการบริหารโครงการหรือระบบการสื่อสารไม่มีประสิทธิภาพ อาจส่งผล ให้เกิดปัญหาตามมามากมาย เช่น ปัญหาเกี่ยวกับความไม่เข้าใจ ปัญหาในการประสานงาน เป็นต้น ซึ่งอาจส่งผลให้ โครงการใช้เวลาในการดำเนินงานที่มากขึ้น และค่าใช้จ่ายที่เพิ่มขึ้น

การทำงานโครงการ เป็นการทำงานที่ตอบสนองความต้องการของลูกค้าได้เป็นอย่างดี เนื่องจากงานโครงการเป็นงานที่ มีลักษณะเป็นเอกลักษณ์ มีวัตถุประสงค์ที่ชัดเจน และมีระยะเวลาในการดำเนินงาน กล่าวคือต้องระบุวันเวลาที่เริ่มต้น และ สิ้นสุดของโครงการ โดยทั่วไปงานโครงการต้องเผชิญกับปัญหาทางการติดต่อสื่อสารในมิติต่างๆที่ส่งผลกระทบทำให้เกิด ความเสียหายทั้งทางตรง และทางอ้อม ทั้งระยะสั้น และระยะยาว เช่น งานเสร็จไม่ทันเวลา เนื่องจากพนักงานไม่เข้าใจคำสั่ง งาน หรือขาดการประสานงานที่ดี ส่งผลให้ต้องเร่งงานในช่วงปลายงาน ทำให้เสียค่าล่วงเวลา และหากทำไม่เสร็จอาจถูก ปรับตามที่ระบุในสัญญา และยังส่งผลต่อความเชื่อมั่น หรือความพึงพอใจจากลูกค้าอีกด้วย ดังนั้นระบบการสื่อสารที่ พัฒนาขึ้นจะเป็นการวางแผนการสื่อสารในงานโครงการ และถือเป็นส่วนหนึ่งของขั้นตอนมาตรฐานตามกรอบการบริหาร โครงการ ISO 10006:2003 [1] ภายใต้ระบบการทำงานโครงการอีพีซีในธุรกิจปิโตรเลียม และปิโตรเคมี

\section{2. ที่มาและความสำคัญของปัญหา}

อุตสาหกรรมปิโตรเลียม และปิโตรเคมี หลายท่านอาจเข้าใจว่าเป็นอุตสาหกรรมที่ไกลตัว ไกลวิถีชีวิตประจำวันของเรา แต่ใน ความเป็นจริงแล้วอุตสาหกรรมปิโตรเคมีถือเป็นอุตสาหกรรมต่อเนื่องอื่นๆ ทำให้เกิดการต่อยอดทางเศรษฐกิจ และการ พัฒนาที่ยั่งยืนของประเทศ รวมทั้งต้องใช้เวลานานในการก่อสร้างโรงงาน และต้นทุนการก่อสร้างที่สูงมาก [2] สำหรับบริษัท กรณีศึกษาเป็นบริษัทที่ทำธุรกิจให้บริการในงานบริหารโครงการวิศวกรรม ในกลุ่มธุรกิจปิโตรเลียม และปิโตรเคมี อาทิเช่น โครงการซ่อมบำรุง การออกแบบ ติดตั้งเครื่องจักรและสิ่งอำนวยความสะดวก การสร้างหรือขยายส่วนต่อโรงงาน เป็นต้น ซึ่ง โครงการเหล่านี้จะมีค่าใช้จ่ายค่อนข้างสูงในการดำเนินโครงการ และมีระยะเวลาการดำเนินการที่จำกัด โดยเฉพาะกลุ่ม โครงการอีพีซี (EPC Project) ซึ่งเป็นโครงการขนาดใหญ่ ประกอบด้วยงานวิศวกรรม (Engineering) งานจัดซื้อ จัดจ้าง (Procurement) และงานก่อสร้าง (Construction) ดังนั้นการดำเนินโครงการจึงต้องมีการติดต่อสื่อสาร และประสานงาน เกิดขึ้นได้ในทุกกิจกรรมของการดำเนินงาน แต่ในปัจจุบันพบว่าบริษัทกรณีศึกษาบริหารการสื่อสารโดยใช้เพียงประสบการณ์ การทำงานที่ผ่านมาจากโครงการในอดีต ประกอบกับประสบการณ์การทำงานของผู้จัดการโครงการ (Project Manager) โดยขาดระบบการสื่อสารที่ใช้ในการดำเนินโครงการอย่างชัดเจน จึงทำให้ประสิทธิภาพของการบริหารการสื่อสารของ โครงการขึ้นอยู่กับความสามารถของผู้จัดการโครงการแต่ละคน ซึ่งอาจส่งผลให้การบริหารการสื่อสารของโครงการล้มเหลว และมีผลต่อความสำเร็จของโครงการ หรืออาจเกิดความขัดแย้งระหว่างบุคคลทั้งภายในและภายนอก ซึ่งจะทำให้เสีย ภาพลักษณ์และชื่อเสียงของบริษัทอีกด้วย

การจัดการเรื่องการสื่อสารของโครงการจึงเป็นสิ่งที่สำคัญต่อการบริหารโครงการเพราะการทำงานโครงการคือการ ทำงานที่ต้องมีการประสานงานกันของหลายคน และหลายหน่วยงาน การสื่อสารที่ไม่เข้าใจกัน คงเป็นไปได้ยากที่โครงการ นั้นจะบรรลุวัตถุประสงค์ หรือประสบความสำเร็จ ปัจจุบันปัญหาที่พบมากที่สุดในการบริหารโครงการมีสาเหตุมาจากการ สื่อสารที่ไม่มีประสิทธิภาพ หรือไม่เพียงพอ การมีระบบการสื่อสารของโครงการอย่างเหมาะสมจะสร้างความเข้าใจร่วมกัน 
ของผู้ที่เกี่ยวข้อง ขจัดข้อขัดแย้ง พัฒนาความสัมพันธ์ระหว่างบุคคล และสื่อสารได้อย่างรวดเร็ว ดังนั้นการบริหารการสื่อสาร จึงเป็นปัจจัยสำคัญที่นำไปสู่ความสำเร็จของโครงการ จากการสอบถามทีมงานบริหารโครงการอีพีซีของบริษัทกรณีศึกษา พบว่าปัญหาที่เกิดขึ้นในโครงการอีพีซี อาทิเช่น ค่าใช้จ่ายเกินงบประมาณ โครงการล่าช้า เกิดการเปลี่ยนแปลงบ่อยครั้ง คุณภาพไม่ได้ตามที่ลูกค้าต้องการ เป็นต้น ปัญหาเหล่านี้ส่วนหนึ่งมีสาเหตุมาจากการสื่อสารที่ไม่เพียงพอหรือไม่มี ประสิทธิภาพ ก่อให้เกิดความเสี่ยงในด้านต่างๆและเกิดความขัดแย้งของสมาชิกในที่มงานโครงการ ซึ่งส่งผลกระทบต่อ คุณภาพและความสำเร็จของโครงการ ดังนั้นการวิจัยนี้จึงต้องการพัฒนาระบบการสื่อสารเพื่อเพิ่มประสิทธิภาพในการ บริหารโครงการอีพีซี

\section{3. ทฤษฎีและงานวิจัยที่เกี่ยวข้อง}

\section{1. ทฤษฎีที่เกี่ยวข้อง}

3.1.1. การบริหารการสื่อสารของโครงการ (Project Communication Management) การบริหารโครงการเป็นเครื่องมือที่สำคัญในการบริหารงานยุคใหม่ และมีการนำมาใช้อย่างแพร่หลาย โดยเฉพาะสำหรับงาน ขนาดใหญ่ งานที่มีลักษณะเฉพาะ และงานที่ต้องการทักษะที่หลากหลาย ซึ่งกระบวนการสื่อสารจะเป็นการแลกเปลี่ยน ข้อมูลที่จำเป็นสำหรับโครงการ

องค์ความรู้ในด้านการบริหารโครงการในปัจจุบัน คือ องค์ความรู้ด้านการบริหารโครงการ ( $A$ Guide to the Project Management Body of Knowledge หรือ PMBOK Guide) [3] ซึ่งได้แบ่งกลุ่มกระบวนการบริหารโครงการและขอบเขต ความรู้ในการจัดการการสื่อสารในโครงการได้ ดังตารางที่ 1

ตารางที่ 1 กลุ่มกระบวนการบริหารโครงการและขอบเขตความรู้ในการจัดการการสื่อสารในโครงการ [3]

\begin{tabular}{|c|c|c|c|c|c|}
\hline \multirow{2}{*}{$\begin{array}{c}\text { ขอบเขต } \\
\text { ความรู้ } \\
\text { (Knowledge } \\
\text { Areas) }\end{array}$} & \multicolumn{5}{|c|}{ กลุ่มกระบวนการบริหารโครงการ (Project Management Process Groups) } \\
\hline & $\begin{array}{c}\text { กลุ่ม } \\
\text { กระบวนการ } \\
\text { ริเริ่มโครงการ }\end{array}$ & $\begin{array}{c}\text { กลุ่ม } \\
\text { กระบวนการ } \\
\text { วางแผน } \\
\text { โครงการ }\end{array}$ & $\begin{array}{c}\text { กลุ่ม } \\
\text { กระบวนการ } \\
\text { บริหารโครงการ }\end{array}$ & $\begin{array}{c}\text { กลุ่ม } \\
\text { กระบวนการ } \\
\text { ติดตามและ } \\
\text { ควบคุมโครงการ }\end{array}$ & $\begin{array}{c}\text { กลุ่ม } \\
\text { กระบวนการ } \\
\text { ปิดโครงการ }\end{array}$ \\
\hline $\begin{array}{l}\text { 10. การจัดการ } \\
\text { การสื่อสารใน } \\
\text { โครงการ }\end{array}$ & $\begin{array}{l}10.1 \text { ระบุผู้มีส่วน } \\
\text { ได้ส่วนเสีย }\end{array}$ & $\begin{array}{l}10.2 \text { วางแผนการ } \\
\text { สื่อสาร }\end{array}$ & $\begin{array}{l}10.3 \text { การ } \\
\text { กระจายข้อมูล } \\
10.4 \text { จัดการกับ } \\
\text { ความคาดหวัง } \\
\text { ของผู้มีส่วนได้ } \\
\text { ส่วนเสีย }\end{array}$ & 10.5 รายงานผล & - \\
\hline
\end{tabular}




\subsection{2. เทคนิคเดลฟาย (Delphi Technique)}

งานวิจัยนี้ได้สัมภาษณ์ และสอบถามข้อมูลจากผู้เชี่ยวชาญ หรือผู้ปฏิบัติงานโครงการอีพีซีภายในบริษัทกรณีศึกษา โดยใช้ เทคนิคเดลฟายซึ่งเป็นวิธีการวินิจฉัยหรือตัดสินใจปัญหาอย่างเป็นระบบ จำนวน 52 คน จากทั้งหมด 6 ส่วนงาน คือ ส่วน งานบริหารโครงการขนาดใหญ่ ส่วนงานบริหารโครงการทั่วไป ส่วนงานวิศวกรรมส่วนกลาง ส่วนงานบริหารงานจัดหา ส่วน งานบริหารงานก่อสร้าง และส่วนงานคุณภาพ ความปลอดภัย อาชีวอนามัยและสิ่งแวดล้อม (QSHE)

\subsection{3. การประเมินความเสี่ยง (Risk Assessment)}

สำหรับงานวิจัยนี้ได้นำทฤษฎีการประเมินความเสี่ยงมาวิเคราะห์และจัดลำดับความสำคัญของปัญหาด้านการสื่อสารที่มี ผลกระทบอย่างชัดเจนทั้งด้านเวลาและค่าใช้จ่าย โดยมีปัจจัยที่สำคัญ 2 ปัจจัย คือ 1.ความรุนแรงของผลกระทบ (Severity, S) ซึ่งในงานวิจัยนี้จะพิจารณาผลกระทบด้านเวลา (Time) และค่าใช้จ่าย (Cost) 2.โอกาสที่จะเกิดความเสี่ยง (Occurrence, O) ซึ่งในงานวิจัยนี้คือ ความถี่ (Frequency) ของการเกิดปัญหา

\subsection{4. แผนผังเหตุและผลหรือแผนผังก้างปลา (Cause and Effect Diagram)}

งานวิจัยนี้ได้ใช้เทคนิคการวิเคราะห์ด้วยแผนผังเหตุและผล เป็นวิธีการระดมสมอง (Brainstorming) และแสดงความคิดเห็น จากผู้เชี่ยวชาญ หรือผู้ปฏิบัติงานโครงการอีพีซีภายในบริษัทกรณีศึกษา สำหรับปัญหาการสื่อสารที่มีคะแนนความเสี่ยงอยู่ ในระดับสูงจะถูกนำมาวิเคราะห์ด้วยเทคนิคนี้เพื่อหาแนวทางการแก้ไขผ่านการพัฒนาระบบการสื่อสาร

\section{2. งานวิจัยที่เกี่ยวข้อง}

พบการวิเคราะห์ปัญหาและผลกระทบของการติดต่อสื่อสารในโครงการก่อสร้างโดยใช้บริษัทรับเหมาก่อสร้างในประเทศไทย เป็นกรณีศึกษา [4] ได้ทำการสำรวจด้วยแบบสอบถามและสัมภาษณ์แบบเจาะลึกจากบุคลากรภายในโครงการก่อสร้าง เพื่อให้ทราบถึงปัญหาด้านต่างๆ ในการดำเนินงานที่มีส่วนเกี่ยวข้องกับการติดต่อสื่อสาร รวมทั้งการรวบรวมข้อมูลจากการ ประชุมประจำเดือนภายในโครงการก่อสร้างของบริษัทตัวอย่าง จากผลการศึกษาพบว่าสิ่งที่ช่วยส่งเสริมให้การติดต่อสื่อสาร มีประสิทธิภาพ คือ ความพร้อมของอุปกรณ์สื่อสารที่จำเป็นต้องมีอย่างเพียงพอ เช่น โทรศัพท์ อินเตอร์เน็ต เป็นต้น เพราะ สภาพงานก่อสร้างมีลักษณะของงานที่ต้องการความเร่งด่วนและรวดเร็วในการประสานงานทุกภาคส่วนจากผู้ปฏิบัติงาน และควรมีการสร้างพื้นฐานความรู้ความเข้าใจให้พนักงานในโครงการ เพื่อให้เข้าใจตรงกันหรือสร้างมาตรฐานในการทำงาน ที่ชัดเจน เช่น การอบรมให้ความรู้แก่พนักงานในตำแหน่งที่เกี่ยวข้องให้เข้าใจสัญลักษณ์หรือข้อมูลอื่นๆ ทางเทคนิคที่ใช้ ติดต่อสื่อสารในโครงการ เป็นต้น รวมทั้งให้มีระบบการติดต่อสื่อสารที่เป็นไปตามกฎเกณฑ์ ช่องทางการสื่อสารที่ชัดเจน เพื่อ ปรับทัศนคติที่ดีต่อผู้ร่วมงานในการรับรู้และตอบสนองต่อข่าวสาร

สำหรับการประยุกต์ใช้ทฤษฎีการประเมินความเสี่ยง นพวรรณ [5] ได้เสนอการบริหารความเสี่ยงของโครงการออกแบบ ตกแต่งภายใน โดยมีการวิเคราะห์ปัจจัยเสี่ยงด้วยการให้คะแนนความเสี่ยงโดยการสอบถามข้อมูลจากผู้เชี่ยวชาญ จากนั้น จึงจัดระดับความเสี่ยงใน 3 ระดับ คือ ความเสี่ยงรุนแรง สูง ปานกลาง และต่ำ แล้วจึงเลือกความเสี่ยงที่อยู่ในระดับสูงมา วิเคราะห์หาสาเหตุโดยใช้แผนผังวิเคราะห์เหตุและผล (Fish Bone Diagram) และเทคนิคการวิเคราะห์แขนงความบกพร่อง (Fault Tree Analysis, FTA) แล้วให้ค่าระดับความเสี่ยง (Risk Priority Number, RPN) ของสาเหตุนั้นๆ เพื่อทำแผนในการ ป้องกัน แก้ไข และควบคุมความเสี่ยง เมื่อนำแผนงานไปปฏิบัติจริงกับโครงการพบว่าค่าระดับความเสี่ยงของทุกความเสี่ยงมี 
ค่าลดลง ระยะเวลาและงบประมาณในการดำเนินโครงการลดลงกว่าที่คาดการณ์ นอกจากนี้งานวิจัย [6] ได้เสนอเทคนิค การวิเคราะห์สาเหตุของลักษณะข้อบกพร่องและผลกระทบที่ใช้ในการบริหารความเสี่ยงของโครงการ (Project Risk Failure Mode and Effects Analysis, RFMEA) ซึ่งนำมาประยุกต์ใช้กับอุตสาหกรรมอิเล็กทรอนิกส์ โดยให้คะแนนผลกระทบที่ เกิดขึ้น (Impact) โอกาสที่เกิด (Likelihood) และการป้องกัน (Detection) จะได้ค่าระดับความเสี่ยง (Risk Priority Number, RPN) และนำคะแนนผลกระทบคูณโอกาสที่เกิดจะได้คะแนนความเสี่ยง (Risk Score) จากนั้นนำทั้ง 2 ค่านี้ไปสร้างกราฟพา เรโต (Pareto Chart) เพื่อหาปัจจัยเสี่ยงที่ควรวางแผนทำการป้องกันมากที่สุด

\section{4. ลักษณะทั่วไปของโครงการอีพีซี และปัญหาจากการสื่อสาร}

\section{1. โครงสร้างของโครงการอีพีซี}

โครงการอีพีซี ประกอบด้วย 3 หน่วยงานใหญ่ คือ หน่วยงานวิศวกรรม (Engineering) หน่วยงานจัดซื้อ จัดจ้าง (Procurement) และหน่วยงานก่อสร้าง (Construction) โครงสร้างของโครงการอีพีซีจึงประกอบด้วยผู้จัดการโครงการ และ ทีมงานของโครงการ ดังรูปที่ 1

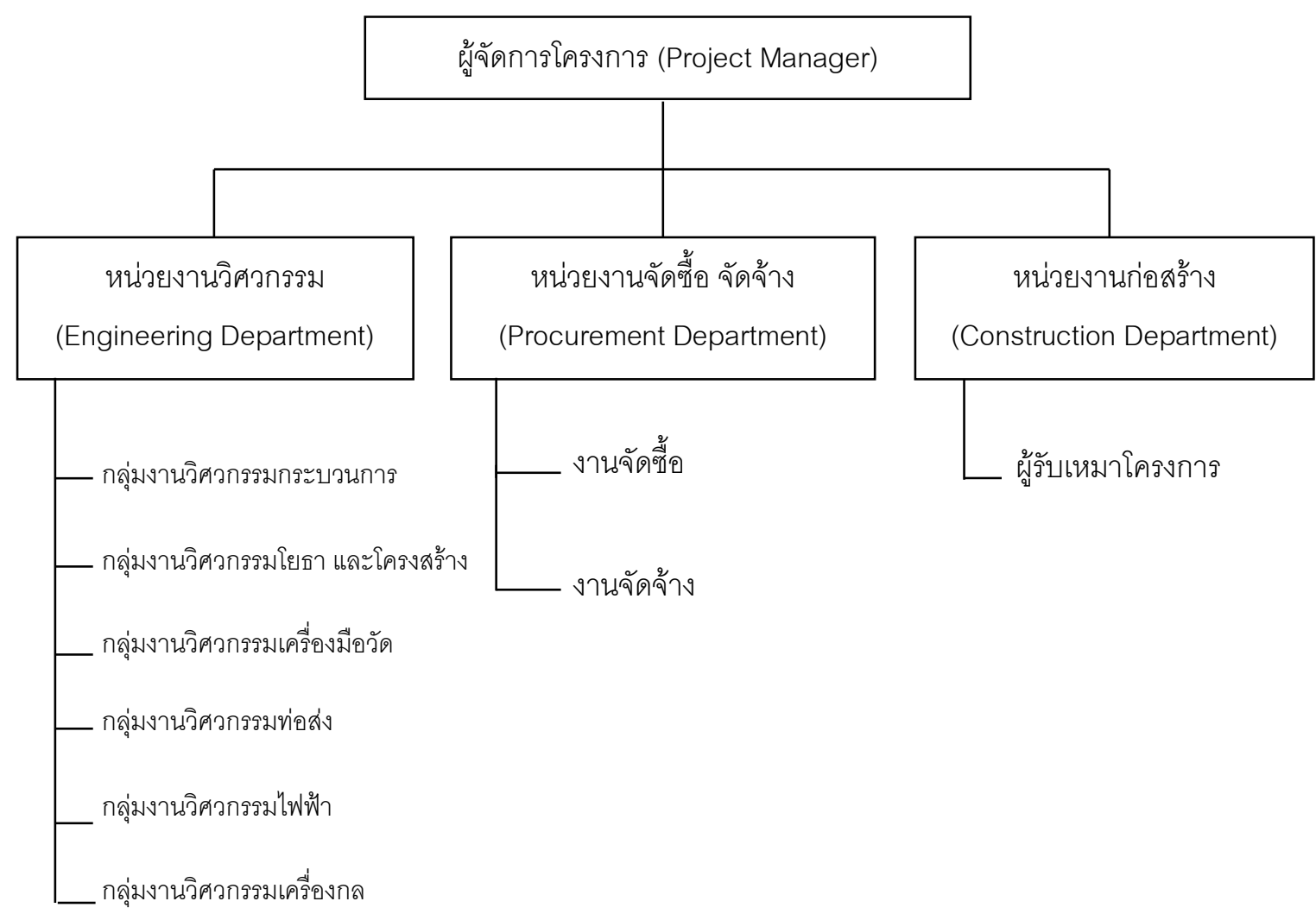

รูปที่ 1 โครงสร้างเบื้องต้นของโครงการอีพีซีของบริษัทกรณีศึกษา 


\section{2. คุณลักษณะของโครงการอีพีซี}

โครงการอีพีซี คือโครงการที่ลูกค้าทำสัญญามอบให้ผู้รับเหมามีบทบาทเป็นผู้บผิดชอบในงานโครงการเพียงรายเดียว โดย เป็นผู้รับผิดชอบทั้งโครงการตั้งแต่การออกแบบ การจัดหาวัสดุและอุปกรณ์ รวมไปจนถึงงานก่อสร้าง ติดตั้ง ทดสอบ ประสิทธิภาพ และอบรมการใช้งาน เนื่องจากสัญญาชนิดนี้ได้รวบรวมความรับผิดชอบมาไว้ที่จุดเดียว ดังนั้นความเสี่ยง ทั้งหมดจึงถูกถ่ายโอนจากเจ้าของโครงการมาอยู่ที่ผู้รับเหมา ประกอบด้วย การรับประกันระยะเวลาในการดำเนินงาน โครงการ คุณภาพ ความปลอดภัย ราคาของสัญญาโครงการ รวมไปถึงความชัดเจนในเรื่องพันธกิจ และความรับผิดชอบต่อ โครงการ โดยแนวโน้มของราคาสัญญานั้นมีมูลค่าค่อนข้างสูงเนื่องจากมีความเสี่ยงในการดำเนินงานที่สูง

\section{3. ปัญหาการสื่อสารที่เกิดขึ้นในโครงการอีพีซี}

ในงานวิจัยนี้ต้องการพัฒนาระบบการสื่อสารเพื่อใช้เป็นแนวทางการสื่อสารของโครงการอีพีซี โดยใช้ข้อมูลจากงานโครงการ อีพีซีของบริษัทกรณีศึกษามาทำการวิเคราะห์ ซึ่งได้รวบรวมโครงการอีพีซีที่มีระยะเวลาการดำเนินงานตามสัญญาอยู่ในช่วง ตั้งแต่เดือน มิถุนายน 2553 ถึง กันยายน 2555 (เดือนสุดท้ายของการเก็บข้อมูล) ซึ่งมีทั้งหมด 5 โครงการ ประกอบด้วย โครงการ $N W, A S, N F, A B$ และWR ซึ่งเป็นชื่อย่อของโครงการอีพีซี ดังตารางที่ 2

ตารางที่ 2 ระยะเวลาดำเนินงานในแต่ละโครงการอีพีซี

\begin{tabular}{cccc}
\hline ลำดับ & รายชื่อโครงการอีพีซี & $\begin{array}{c}\text { ช่วงที่เริ่มดำเนินงานตาม } \\
\text { สัญญาโครงการ }\end{array}$ & $\begin{array}{c}\text { ช่วงที่สิ้นสุดการดำเนินงานตาม } \\
\text { สัญญาโครงการ }\end{array}$ \\
\hline 1 & $\mathrm{NW}$ & มิถุนายน พ.ศ. 2553 & มีนาคม พ.ศ. 2555 \\
2 & $\mathrm{AS}$ & กันยายน พ.ศ. 2554 & กันยายน พ.ศ. 2555 \\
3 & $\mathrm{NF}$ & กันยายน พ.ศ. 2554 & กันยายน พ.ศ. 2555 \\
4 & $\mathrm{AB}$ & กันยายน พ.ศ. 2554 & กรกฎาคม พ.ศ. 2555 \\
5 & $\mathrm{WR}$ & เมษายน พ.ศ. 2554 & กันยายน พ.ศ. 2555 \\
\hline
\end{tabular}

จากการทบทวนเอกสารบันทึกการประชุมรายสัปดาห์ (Minutes of Meeting) รายงานโครงการประจำเดือน (Monthly Report) รายงานสรุปผลการดำเนินงานโครงการ (Project Closeout Report) และแบบสำรวจความพึงพอใจลูกค้า (Customer Satisfaction Survey) ควบคู่ไปกับการสอบถาม (Interview) ผู้จัดการโครงการ วิศวกรผู้ปฏิบัติงานในทีมงาน โครงการ และพนักงานที่เกี่ยวข้องในงานโครงการทั้ง 5 โครงการเพื่อทำการตรวจสอบ และระบุปัญหาการสื่อสารที่เกิดขึ้น เพิ่มเติม ซึ่งปัญหาการสื่อสารที่เกิดขึ้นจากการดำเนินงานทั้งหมดมี 48 รายการ โดยแบ่งตามการประสานงานระหว่าง หน่วยงานที่เกี่ยวข้อง คือ ปัญหาการสื่อสารที่เกิดขึ้นระหว่างหน่วยงานวิศวกรรมและหน่วยงานจัดซื้อ จัดจ้าง $(E-P)$ มีจำนวน 10 รายการ ปัญหาการสื่อสารที่เกิดขึ้นระหว่างหน่วยงานวิศวกรรมและหน่วยงานก่อสร้าง $(E-C)$ มีจำนวน 7 รายการ ปัญหา การสื่อสารที่เกิดขึ้นระหว่างหน่วยงานก่อสร้างและหน่วยงานจัดซื้อ จัดจ้าง (C-P) มีจำนวน 13 รายการ ปัญหาการสื่อสารที่ เกี่ยวข้องทั้ง 3 หน่วยงาน $(E-P-C)$ มีจำนวน 5 รายการ ปัญหาการสื่อสารภายในหน่วยงานวิศวกรรม $(E)$ มีจำนวน 8 รายการ ปัญหาการสื่อสารภายในหน่วยงานจัดซื้อ จัดจ้าง (P) มีจำนวน 4 รายการ และปัญหาการสื่อสารภายในหน่วยงานก่อสร้าง (C) มีจำนวน 1 รายการ แสดงได้ดังตารางที่ 3 
ตารางที่ 3 รายการปัญหาการสื่อสารตามการประสานงานระหว่างหน่วยงานที่เกี่ยวข้อง

ลำดับ รายการปัญหาการสื่อสาร

เกี่ยวข้องระหว่าง

หน่วยงาน

\begin{tabular}{|c|c|c|}
\hline 1 & เอกสารเรียกร้องการสั่งซื้อ (Requisition) ของหน่วยงานวิศวกรรมไม่สมบูรณ์ & E-P \\
\hline 2 & $\begin{array}{l}\text { หน่วยงานวิศวกรรม ส่ง รายละเอียดของแบบงานไม่ชัดเจนหรือไม่ครบถ้วนให้กับหน่วยงาน } \\
\text { จัดซื้อ จัดจ้าง }\end{array}$ & E-P \\
\hline 3 & แบบงานที่ส่งให้หน่วยงานจัดซื้อ จัดจ้างเพื่อทำการสั่งซื้อ ไม่ได้อัพเดตข้อมูลล่าสุด & E-P \\
\hline 4 & วัสดุที่ออกแบบหาซื้อได้ยาก หรือไม่สามารถจัดซื้อได้ในช่วงเวลาที่ต้องการ & E-P \\
\hline 5 & $\begin{array}{l}\text { ที่มงานอ่านข้อกำหนดและข้อมูลทางเทคนิคไม่ครบถ้วน จนทำให้การเปรียบเทียบราคาจาก } \\
\text { ผู้ขาย (Vendor) ผิดพลาด }\end{array}$ & E-P \\
\hline 6 & หน่วยงานจัดซื้อ จัดจ้างสั่งซื้อสินค้าผิดสเปคจากแบบงาน & E-P \\
\hline 7 & ข้อมูลรายชื่อผู้ขายหรือผู้ผลิต (Vendor list) ไม่เพียงพอในการคัดเลือก & E-P \\
\hline 8 & $\begin{array}{l}\text { หน่วยงานจัดซื้อ จัดจ้าง ออกใบสั่งซื้อ (Purchase Order) ที่ยังไม่ได้อัพเดตข้อมูลล่าสุด ทำ } \\
\text { ให้ต้องแก้ไขใบสั่งซื้อใหม่ }\end{array}$ & E-P \\
\hline 9 & $\begin{array}{l}\text { ลูกค้าไม่ได้รับเอกสารข้อมูลทางเทคนิคของวัสดุหรืออุปกรณ์ หรือลูกค้าได้รับเอกสารไม่ } \\
\text { ครบถ้วน }\end{array}$ & E-P \\
\hline 10 & การตกลงรายละเอียดของสัญญาระหว่างบริษัทกับผู้ขาย (Vendor) ยังไม่ชัดเจน & E-P \\
\hline 11 & ขาดการประสานงานในการติดตั้งอุปกรณ์ที่หน้างาน & $\mathrm{E}-\mathrm{C}$ \\
\hline 12 & $\begin{array}{l}\text { หน่วยงานก่อสร้างได้รับแบบงานที่มีสถานะก่อสร้างได้ (Drawing for Construction) ล่าช้า } \\
\text { กว่ากำหนด }\end{array}$ & $\mathrm{E}-\mathrm{C}$ \\
\hline 13 & แบบงานที่มีสถานะก่อสร้างได้ (Drawing for Construction) ไม่ได้อัพเดตข้อมูลล่าสุด & $\mathrm{E}-\mathrm{C}$ \\
\hline 14 & ขาดการประสานงานทำให้เกิดความเข้าใจผิดในแบบงาน & $\mathrm{E}-\mathrm{C}$ \\
\hline 15 & แบบงานไม่เหมาะสม หรือไม่สามารถนำไปใช้งานได้จริงและต้องมีการแก้ไข & $\mathrm{E}-\mathrm{C}$ \\
\hline 16 & ขาดการประสานงานทำให้การก่อสร้างผิดจากแบบงาน & $\mathrm{E}-\mathrm{C}$ \\
\hline 17 & ผู้ควบคุมงานก่อสร้างไม่เข้าใจในแบบงาน & $\mathrm{E}-\mathrm{C}$ \\
\hline 18 & ปัญหาการเลือกผู้รับเหมาที่ไม่มีประสิทธิภาพมาทำงาน & C-P \\
\hline 19 & มีปัญหาด้านการจัดส่งสินค้าเรื่องรายละเอียดของบรรจุภัณฑ์ (Packing list) & C-P \\
\hline 20 & $\begin{array}{l}\text { หน่วยงานก่อสร้างได้รับวัสดุ หรืออุปกรณ์ล่าช้ากว่ากำหนด หรือการจ้างผู้รับเหมาล่าช้ากว่า } \\
\text { กำหนด }\end{array}$ & C-P \\
\hline 21 & หน่วยงานก่อสร้างได้รับวัสดุผิดสเปค & C-P \\
\hline 22 & ผู้รับเหมาเลือกวัสดุ และอุปกรณ์ไม่เหมาะสมในการก่อสร้าง & C-P \\
\hline 23 & ผู้รับเหมาขาดความเข้าใจในการติดตั้งอุปกรณ์ที่หน้างาน & C-P \\
\hline 24 & $\begin{array}{l}\text { หน่วยงานจัดซื้อ จัดจ้างลดขอบเขตการทำงานของผู้รับเหมา แต่ไม่ได้แจ้งให้ทางหน่วยงาน } \\
\text { ก่อสร้างทราบ }\end{array}$ & C-P \\
\hline
\end{tabular}


ตารางที่ 3 (ต่อ) รายการปัญหาการสื่อสารตามการประสานงานระหว่างหน่วยงานที่เกี่ยวข้อง

\begin{tabular}{|c|c|c|}
\hline ลำดับ & รายการปัญหาการสื่อสาร & $\begin{array}{l}\text { เกี่ยวข้องระหว่าง } \\
\text { หน่วยงาน }\end{array}$ \\
\hline 25 & $\begin{array}{l}\text { พนักงานของบริษัทผู้รับเหมาไม่สามารถเข้าทำงานได้เนื่องจากไม่ปฏิบัติตามกฎระเบียบ } \\
\text { ของบริษัท หรือกฎหมาย }\end{array}$ & C-P \\
\hline 26 & พนักงานของบริษัทผู้รับเหมาไม่ทราบกฎเกณฑ์ด้านความปลอดภัย & C-P \\
\hline 27 & $\begin{array}{l}\text { บริษัทผู้รับเหมาทำงานไม่ได้ตามแบบงาน และใช้วัสดุไม่เป็นไปตามข้อมูลทางเทคนิค } \\
\text { (Data Sheet) }\end{array}$ & C-P \\
\hline 28 & $\begin{array}{l}\text { ขาดการประสานงานกับหน่วยงานจัดซื้อ จัดจ้างทำให้หน่วยงานก่อสร้างจัดลำดับงาน } \\
\text { ก่อสร้างผิด }\end{array}$ & C-P \\
\hline 29 & อุปกรณ์ที่ใช้ในการก่อสร้างของผู้รับเหมาไม่ผ่านเกณฑ์ความปลอดภัย & C-P \\
\hline 30 & ผู้รับเหมาไม่ได้ดำเนินงานตามที่ระบุในสัญญาว่าจ้าง & C-P \\
\hline 31 & รายละเอียดขอบเขตการทำงาน (Scope of Work) ของสัญญายังไม่ชัดเจน & E-P-C \\
\hline 32 & $\begin{array}{l}\text { พนักงานที่เกี่ยวข้องในโครงการบางคนยังไม่รู้คำจำกัดความของเอกสาร หรือไม่เข้าใจใน } \\
\text { แบบฟอร์มต่างๆ }\end{array}$ & E-P-C \\
\hline 33 & ขอบเขตความรับผิดชอบของพนักงานในทีมโครงการไม่ชัดเจน & E-P-C \\
\hline 34 & $\begin{array}{l}\text { พนักงานใหม่ในที่มงานโครงการยังไม่ทราบระเบียบขั้นตอนการปฏิบัติงาน (Procedure) ที่ } \\
\text { เกี่ยวข้องในงาน }\end{array}$ & E-P-C \\
\hline 35 & พนักงานในทีมโครงการขาดความเข้าใจในกฎหมายใหม่ & E-P-C \\
\hline 36 & การกระจายข้อมูลเกี่ยวกับการเปลี่ยนแปลงรายละเอียดงานจากลูกค้าไม่ทั่วถึง & $\mathrm{E}$ \\
\hline 37 & การกระจายข้อมูลข่าวสารไม่ทั่วถึง ทำให้ผู้เกี่ยวข้องบางคนไม่ได้รับข้อมูล & E \\
\hline 38 & ออกแบบไม่ครบถ้วนทำให้เกิดการแก้ไขงาน (Design Change) ภายหลัง & E \\
\hline 39 & $\begin{array}{l}\text { ขาดการติดต่อประสานงานระหว่างกลุ่มงานในหน่วยงานวิศวกรรม (Discipline) ทำให้เกิด } \\
\text { การแก้ไขแบบงาน }\end{array}$ & E \\
\hline 40 & รายละเอียดแบบงานที่ส่งต่อระหว่างกลุ่มงานในหน่วยงานวิศวกรรมไม่อัพเดต & E \\
\hline 41 & ลูกค้าให้ข้อมูลรายละเอียดโครงการล่าช้า & E \\
\hline 42 & หน่วยงานวิศวกรรมออกแบบไม่ตรงตามมาตรฐาน & E \\
\hline 43 & ความล่าช้าในการประสานงานเพื่อแก้ไขกรณีซอฟต์แวร์ใช้งานไม่ได้ & E \\
\hline 44 & เกิดเหตุการณ์การปฏิบัติงานของผู้รับเหมาไม่สอดคล้องตามข้อกฎหมาย & $P$ \\
\hline 45 & พนักงานของบริษัทผู้รับเหมาไม่ปฏิบัติตามระเบียบขั้นตอนการปฏิบัติงาน (Procedure) & $P$ \\
\hline 46 & หน่วยงานจัดซื้อ จัดจ้างขาดการติดต่อประสานงานกับผู้ขาย (Vendor) อย่างต่อเนื่อง & $P$ \\
\hline 47 & ผู้ขาย (Vendor) สงสินค้ามาไม่ตรงกับใบสั่งซื้อ (Purchase Order) & $P$ \\
\hline 48 & ความขัดแย้งระหว่างผู้ควบคุมงานก่อสร้างกับเจ้าหน้าที่ความปลอดภัย & C \\
\hline
\end{tabular}




\section{5. การพัฒนาระบบการสื่อสาร}

\section{1. การประยุกต์ใช้ทฤษฎีการประเมินความเสี่ยง (Risk Assessment)}

เนื่องจากว่าปัญหาการสื่อสารที่เกิดขึ้นใน 5 โครงการอีพีซีได้ส่งผลกระทบต่อเวลาและต้นทุนไม่เท่ากัน และมีความถี่ของการ เกิดปัญหาการสื่อสารที่แตกต่างกัน ดังนั้นเมื่อต้องการทราบว่าปัญหาการสื่อสารใดที่มีความสำคัญ และรุนแรง ซึ่งควรได้รับ การแก้ไขอย่างเร่งด่วน การวิจัยนี้จึงใช้ทฤษฎีการประเมินความเสี่ยง (Risk Assessment) มาช่วยในการวิเคราะห์ โดยเริ่มต้น จากการกำหนดเกณฑ์ประเมินความเสี่ยง ซึ่งแบ่งได้เป็น 2 เกณฑ์ คือ เกณฑ์ความรุนแรงของผลกระทบ (Severity; S) ดัง ตารางที่ 4 และเกณฑ์ของโอกาส (Occurrence; O) หรือความถี่ในการเกิดปัญหาการสื่อสาร ดังตารางที่ 5 ซึ่งเกณฑ์จะถูก กำหนดจากประสบการณ์ของผู้บริหาร และวิศวกรผู้เชี่ยวชาญในการบริหารโครงการภายในบริษัทกรณีศึกษา เกณฑ์ที่ถูก กำหนดจะแสดงค่าเป็นเปอร์เซ็นต์ที่เหมาะสม และยอมรับได้ โดยผู้มีความเชี่ยวชาญในการบริหารโครงการ และผู้ปฏิบัติงาน ที่ดำรงตำแหน่งที่เกี่ยวข้องในโครงการจะเป็นผู้ที่ประเมินให้คะแนนความเสี่ยง เมื่อได้คะแนนความเสี่ยง หรือคะแนน ความสำคัญ และรุนแรงของปัญหาการสื่อสารทั้งหมดแล้วจะถูกนำมาเทียบในตารางจัดลำดับความสำคัญของความเสี่ยง ที่ คณะกรรมการบริหารโครงการ (Project Management Office) ของบริษัทกรณีศึกษากำหนดขึ้น ดังตารางที่ 6

ตารางที่ 4 เกณฑ์ระดับคะแนนความรุนแรงของผลกระทบที่เกิดขึ้น

\begin{tabular}{|c|c|c|c|c|c|}
\hline \multirow[b]{2}{*}{ ผลกระทบ } & \multicolumn{5}{|c|}{ ระดับคะแนนความรุนแรงของผลกระทบ (Severity; S) } \\
\hline & $\begin{array}{c}1 \\
\text { รุนแรงน้อยมาก } \\
\text { (Insignificant) }\end{array}$ & $\begin{array}{c}2 \\
\text { รุนแรงน้อย } \\
\text { (Minor) }\end{array}$ & $\begin{array}{c}3 \\
\text { รุนแรงปานกลาง } \\
\text { (Moderate) }\end{array}$ & $\begin{array}{c}4 \\
\text { รุนแรงมาก } \\
\text { (Major) }\end{array}$ & $\begin{array}{c}5 \\
\text { รุนแรงมากที่สุด } \\
\text { (Catastrophic) }\end{array}$ \\
\hline เวลา & $\begin{array}{l}\text { งานล่าช้ากว่าแผน } \\
\text { ไม่เกิน } 5 \%\end{array}$ & $\begin{array}{l}\text { งานล่าช้ากว่า } \\
\text { แผน } 5 \% \text { แต่ } \\
\text { ไม่เกิน } 10 \%\end{array}$ & $\begin{array}{l}\text { งานล่าช้ากว่า } \\
\text { แผน } 10 \% \text { แต่ } \\
\text { ไม่เกิน } 15 \%\end{array}$ & $\begin{array}{l}\text { งานล่าช้ากว่า } \\
\text { แผน } 15 \% \text { แต่ } \\
\text { ไม่เกิน } 20 \%\end{array}$ & $\begin{array}{l}\text { งานล่าช้ากว่า } \\
\text { แผนตั้งแต่ } \\
20 \text { \%ขึ้นไป }\end{array}$ \\
\hline ค่าใช้จ่าย & $\begin{array}{c}\text { น้อยกว่า } 0.1 \% \text { ของ } \\
\text { มูลค่าโครงการ }\end{array}$ & $\begin{array}{c}\text { ตั้งแต่ } 0.1 \% \text { แต่ } \\
\text { ไม่เกิน } 0.5 \% \text { ของ } \\
\text { มูลค่าโครงการ }\end{array}$ & $\begin{array}{c}\text { ตั้งแต่ } 0.5 \% \text { แต่ไม่ } \\
\text { เกิน } 1 \% \text { ของมูลค่า } \\
\text { โครงการ }\end{array}$ & $\begin{array}{l}\text { ตั้งแต่ } 1 \% \text { แต่ } \\
\text { ไม่เกิน } 5 \% \text { ของ } \\
\text { มูลค่าโครงการ }\end{array}$ & $\begin{array}{c}\text { มากกว่า } 5 \% \text { ของ } \\
\text { มูลค่าโครงการ }\end{array}$ \\
\hline
\end{tabular}

ตารางที่ 5 เกณฑ์ระดับคะแนนโอกาส หรือความถี่ของการเกิดปัญหาการสื่อสาร

\begin{tabular}{ccc}
\hline $\begin{array}{c}\text { ระดับ } \\
\text { คะแนน }\end{array}$ & $\begin{array}{c}\text { โอกาส (Occurrence; O) } \\
\text { หรือความถี่การเกิดปัญหา }\end{array}$ & คำอธิบาย \\
\hline 1 & น้อยมาก & ความถี่ในการเกิดต่ำกว่า $5 \%$ ของจำนวนงานทั้งหมดต่อโครงการ \\
\cline { 2 - 3 } 2 & ค้อย & ความถี่ในการเกิดตั้งแต่ $5 \%$ ถึง $10 \%$ ของจำนวนงานทั้งหมดต่อโครงการ \\
\cline { 2 - 3 } 3 & ความครั้ง & ความถี่ในการเกิดตั้งแต้ $11 \%$ ถึง $20 \%$ ของจำนวนงานทั้งหมดต่อโครงการ $21 \%$ ถึง $40 \%$ ของจำนวนงานทั้งหมดต่อโครงการ \\
\cline { 2 - 3 } 5 & บ่อย & ความถี่ในการเกิดมากกว่า $40 \%$ ของจำนวนงานทั้งหมดต่อโครงการ \\
\hline
\end{tabular}


ตารางที่ 6 ระดับคะแนนความเสี่ยง $(\mathrm{S} \times \mathrm{O})$ ที่คณะกรรมการบริหารโครงการกำหนดขึ้น

\begin{tabular}{|c|c|c|}
\hline $\begin{array}{c}\text { ระดับคะแนน } \\
(\mathrm{S} \times \mathrm{O})\end{array}$ & ระดับความเสี่ยง & คำอธิบาย \\
\hline $20-25$ & $\begin{array}{c}\text { สูงมาก } \\
\text { (Extremely high) }\end{array}$ & $\begin{array}{l}\text { ไม่สามารถยอมรับได้ เป็นความเสี่ยงที่ต้องรีบจัดการระดับความเสี่ยงให้ } \\
\text { ลดลง โดยมีการกำหนดมาตรการในการจัดการความเสี่ยงเพิ่มเติมโดยทันที }\end{array}$ \\
\hline $10-16$ & $\begin{array}{c}\text { สูง } \\
\text { (High) }\end{array}$ & ไม่สามารถยอมรับได้จะต้องจัดการความเสี่ยงให้อยู่ในระดับที่ยอมรับได้ \\
\hline $3-9$ & $\begin{array}{l}\text { ปานกลาง } \\
\text { (Moderate) }\end{array}$ & $\begin{array}{l}\text { ยอมรับได้ แต่ต้องควบคุมโดยปฏิบัติตามระบบควบคุมภายใน เพื่อไม่ให้มี } \\
\text { ระดับความเสี่ยงเพิ่มขึ้น }\end{array}$ \\
\hline $1-2$ & $\begin{array}{c}\text { ต่ำ } \\
\text { (Low) }\end{array}$ & $\begin{array}{l}\text { ยอมรับได้ โดยไม่จำเป็นต้องมีมาตรการเพิ่มเติมใดๆ แต่ควรมีมาตรการ } \\
\text { ติดตามและดูแล }\end{array}$ \\
\hline
\end{tabular}

\subsection{1. การประเมินคะแนนความเสี่ยง}

ในการประเมินให้คะแนนปัญหาการสื่อสารได้มีการสร้างตารางแบบสอบถาม โดยใช้เทคนิคเดลฟาย (Delphi Technique) คือ การนำแบบสอบถามไปสอบถาม หรือสัมภาษณ์บุคลากรผู้เชี่ยวชาญในงานโครงการ เพื่อประเมินคะแนนความรุนแรง ของผลกระทบ และโอกาส หรือความถี่ของการเกิดปัญหาการสื่อสาร เมื่อได้คะแนนมาแล้ว ต้องดูว่าคะแนนเป็นไปในทิศทาง เดียวกันหรือไม่ ถ้าหากว่าคะแนนมีความแตกต่างกันมาก ผู้วิจัยจำเป็นต้องนำคะแนนที่ได้ไปสอบถามจากผู้ประเมินอีกครั้ง

\subsubsection{1. การประเมินคะแนนความรุนแรงของผลกระทบ (Severity, S)}

เมื่อพิจารณาคะแนนความรุนแรงของผลกระทบ (Severity; S) พบว่าบางปัญหาการสื่อสารอาจเกิดผลกระทบทั้ง 2 ปัจจัยคือ ผลกระทบด้านเวลา และค่าใช้จ่าย ซึ่งทำให้เกิดความแตกต่างของคะแนนความรุนแรงของผลกระทบในปัญหาการสื่อสารนั้น ดังนั้นในการประเมินความรุนแรงของผลกระทบสำหรับงานวิจัยนี้จะเลือกคะแนนที่มากสุด (Mode) ของคะแนนประเมิน เช่น ผลการประเมินของปัญหาการสื่อสารรายการหนึ่ง มีคะแนนประเมินผลกระทบต่อเวลาอยู่ในระดับที่ 2 และมีคะแนน ประเมินผลกระทบต่อค่าใช้จ่ายอยู่ในระดับที่ 3 ผลลัพธ์ของคะแนนความรุนแรงคือ 3 เป็นต้น สำหรับรายการปัญหาที่ถูก ประเมินโดยบุคคลผู้เชี่ยวชาญในงานโครงการจำนวนตั้งแต่ 2 คนขึ้นไป จะใช้ค่าเฉลี่ยโดยการนำผลรวมของการประเมิน คะแนนจากผู้ประเมินที่เกี่ยวข้องหารด้วยจำนวนผู้ประเมินทั้งหมด (Arithmetic Mean) ประกอบกับค่าความแปรปรวนของ การประเมิน เมื่อค่าเฉลี่ยของการประเมินมีค่าเป็นเลขทศนิยม ให้ปัดจุดทศนิยมขึ้นเป็นจำนวนเต็มทุกกรณี

5.1.1.2. การประเมินคะแนนโอกาส หรือความถี่ (Occurrence; O) ของการเกิดปัญหาการสื่อสาร เนื่องจากความถี่ของการเกิดปัญหาการสื่อสารไม่สามารถระบุเป็นตัวเลขที่ชัดเจนได้ จึงได้มีการกำหนดค่าของความถี่เป็น เปอร์เซ็นต์ของจำนวนงานทั้งหมดต่อโครงการ เพื่อให้เกิดความผิดพลาดน้อยที่สุดในการประเมิน ดังนั้นผู้ประเมินจะประเมิน ได้เฉพาะปัญหาการสื่อสารที่เกิดขึ้นในโครงการที่ผู้ประเมินได้ดำเนินงานเท่านั้น เช่น ผู้จัดการโครงการ $A S$ สามารถประเมิน ได้เฉพาะปัญหาการสื่อสารที่เกิดขึ้นในโครงการ $A S$ เท่านั้น ซึ่งกรณีของการประเมินคะแนนโอกาส หรือความถี่ของการเกิด ปัญหาการสื่อสารจะมีจำนวนตั้งแต่ 2 คนขึ้นไป ดังนั้นในการประเมินจะเลือกคะแนนที่มากสุด (Mode) มาใช้ในการประเมิน ความเสี่ยง 


\subsection{2. ปัญหาการสื่อสารที่ควรเร่งดำเนินการแก้ไข}

จากการนำผลคะแนนความรุนแรงของผลกระทบ (S) คูณกับผลคะแนนความถี่ของการเกิดปัญหาการ $(\mathrm{O})$ จะได้ผลคะแนน ความเสี่ยง $(S \times O)$ เมื่อนำผลคะแนนที่ได้ไปเทียบเกณฑ์ความสำคัญของความเสี่ยงในตารางที่ 5 พบว่าไม่มีปัญหาการ สื่อสารที่มีคะแนนความเสี่ยงอยู่ในระดับสูงมาก แต่มีปัญหาการสื่อสารที่มีคะแนนความเสี่ยงอยู่ในระดับสูง และควรเร่ง ดำเนินการแก้ไขจำนวน 28 รายการแสดงดังตารางที่ 7 ซึ่งประกอบด้วยปัญหาการสื่อสารที่เกิดขึ้นระหว่างหน่วยงาน $E-P$ จำนวน 5 รายการ, $E-C$ จำนวน 3 รายการ, C-P จำนวน 8 รายการ, E-P-C จำนวน 3 รายการ, $E$ จำนวน 5 รายการ และ $P$ จำนวน 4 รายการ

ตารางที่ 7 รายการปัญหาการสื่อสารที่มีคะแนนความเสี่ยงอยู่ในระดับสูง และควรเร่งดำเนินการแก้ไข

\begin{tabular}{lcc}
\hline ลำดับ & $\begin{array}{c}\text { เกี่ยวข้อง } \\
\text { รายการปัญหาการสื่อสาร }\end{array}$ & $\begin{array}{c}\text { คะแนน } \\
\text { หน่วยงาน }\end{array}$ \\
& ความเสี่ยง \\
\hline
\end{tabular}

\begin{tabular}{|c|c|c|c|}
\hline 1 & $\begin{array}{l}\text { แบบงานที่ส่งให้หน่วยงานจัดซื้อ จัดจ้างเพื่อทำการสั่งซื้อ ไม่ได้อัพเดตข้อมูล } \\
\text { ล่าสุด }\end{array}$ & E-P & 16 \\
\hline 2 & $\begin{array}{l}\text { หน่วยงานก่อสร้างได้รับแบบงานที่มีสถานะก่อสร้างได้ (Drawing for } \\
\text { Construction) ล่าช้ากว่ากำหนด }\end{array}$ & E-C & 16 \\
\hline 3 & $\begin{array}{l}\text { แบบงานที่มีสถานะก่อสร้างได้ (Drawing for Construction) ไม่ได้อัพเดต } \\
\text { ข้อมูลล่าสุด }\end{array}$ & $\mathrm{E}-\mathrm{C}$ & 16 \\
\hline 4 & $\begin{array}{l}\text { การกระจายข้อมูลเกี่ยวกับการเปลี่ยนแปลงรายละเอียดงานจากลูกค้าไม่ } \\
\text { ทั่วถึง }\end{array}$ & E & 16 \\
\hline 5 & $\begin{array}{l}\text { ขาดการติดต่อประสานงานระหว่างกลุ่มงานในหน่วยงานวิศวกรรม } \\
\text { (Discipline) ทำให้เกิดการแก้ไขแบบงาน }\end{array}$ & E & 16 \\
\hline 6 & $\begin{array}{l}\text { บริษัทผู้รับเหมาทำงานไม่ได้ตามแบบงาน และใช้วัสดุไม่เป็นไปตามข้อมูล } \\
\text { ทางเทคนิค (Data sheet) }\end{array}$ & C-P & 15 \\
\hline 7 & $\begin{array}{l}\text { หน่วยงานวิศวกรรม ส่ง รายละเอียดของแบบงานไม่ชัดเจนหรือไม่ครบถ้วน } \\
\text { ให้กับหน่วยงานจัดซื้อ จัดจ้าง }\end{array}$ & E-P & 12 \\
\hline 8 & หน่วยงานจัดซื้อ จัดจ้างสั่งซื้อสินค้าผิดสเปคจากแบบงาน & E-P & 12 \\
\hline 9 & $\begin{array}{l}\text { หน่วยงานจัดซื้อ จัดจ้าง ออกใบสั่งซื้อ (Purchase Order) ที่ยังไม่ได้อัพเดต } \\
\text { ข้อมูลล่าสุด ทำให้ต้องแก้ไขใบสั่งซื้อใหม่ }\end{array}$ & E-P & 12 \\
\hline 10 & $\begin{array}{l}\text { ลูกค้าไม่ได้รับเอกสารข้อมูลทางเทคนิคของวัสดุหรืออุปกรณ์ หรือลูกค้าได้รับ } \\
\text { เอกสารไม่ครบถ้วน }\end{array}$ & E-P & 12 \\
\hline 11 & แบบงานไม่เหมาะสม หรือไม่สามารถนำไปใช้งานได้จริงและต้องมีการแก้ไข & $\mathrm{E}-\mathrm{C}$ & 12 \\
\hline
\end{tabular}


ตารางที่ 7 (ต่อ) รายการปัญหาการสื่อสารที่มีคะแนนความเสี่ยงอยู่ในระดับสูง และควรเร่งดำเนินการแก้ไข

\begin{tabular}{|c|c|c|c|}
\hline ลำดับ & รายการปัญหาการสื่อสารที่มีคะแนนความเสี่ยงอยู่ในระดับสูง & $\begin{array}{l}\text { เกี่ยวข้อง } \\
\text { ระหว่าง } \\
\text { หน่วยงาน }\end{array}$ & $\begin{array}{l}\text { คะแนน } \\
\text { ความเสี่ยง }\end{array}$ \\
\hline 12 & ปัญหาการเลือกผู้รับเหมาที่ไม่มีประสิทธิภาพมาทำงาน & C-P & 12 \\
\hline 13 & หน่วยงานก่อสร้างได้รับวัสดุผิดสเปค & C-P & 12 \\
\hline 14 & $\begin{array}{l}\text { หน่วยงานก่อสร้างได้รับวัสดุหรืออุปกรณ์ล่าช้ากว่ากำหนด หรือการจ้าง } \\
\text { ผู้รับเหมา ล่าช้ากว่ากำหนด }\end{array}$ & C-P & 12 \\
\hline 15 & $\begin{array}{l}\text { พนักงานของบริษัทผู้รับเหมาไม่สามารถเข้าทำงานได้เนื่องจากไม่ปฏิบัติตาม } \\
\text { กฎระเบียบของบริษัท หรือกฎหมาย }\end{array}$ & C-P & 12 \\
\hline 16 & พนักงานของบริษัทผู้รับเหมาไม่ทราบกฎเกณฑ์ด้านความปลอดภัย & C-P & 12 \\
\hline 17 & อุปกรณ์ที่ใช้ในการก่อสร้างของผู้รับเหมาไม่ผ่านเกณฑ์ความปลอดภัย & C-P & 12 \\
\hline 18 & ผู้รับเหมาไม่ได้ดำเนินงานตามที่ระบุในสัญญาว่าจ้าง & C-P & 12 \\
\hline 19 & $\begin{array}{l}\text { พนักงานที่เกี่ยวข้องในโครงการบางคนยังไม่รู้คำจำกัดความของเอกสาร } \\
\text { หรือไม่เข้าใจในแบบฟอร์มต่างๆ }\end{array}$ & E-P-C & 12 \\
\hline 20 & $\begin{array}{l}\text { พนักงานใหม่ในที่มงานโครงการยังไม่ทราบระเบียบขั้นตอนการปฏิบัติงาน } \\
\text { (Procedure) ที่เกี่ยวข้องในงาน }\end{array}$ & E-P-C & 12 \\
\hline 21 & พนักงานในทีมโครงการขาดความเข้าใจในกฎหมายใหม่ & E-P-C & 12 \\
\hline 22 & การกระจายข้อมูลข่าวสารไม่ทั่วถึง ทำให้ผู้เกี่ยวข้องบางคนไม่ได้รับข้อมูล & E & 12 \\
\hline 23 & ออกแบบไม่ครบถ้วนทำให้เกิดการแก้ไขงาน (Design Change) ภายหลัง & $E$ & 12 \\
\hline 24 & $\begin{array}{l}\text { รายละเอียดแบบงานที่ส่งต่อระหว่างกลุ่มงานในหน่วยงานวิศวกรรมไม่ } \\
\text { อัพเดต }\end{array}$ & E & 12 \\
\hline 25 & เกิดเหตุการณ์การปฏิบัติงานของผู้รับเหมาไม่สอดคล้องตามข้อกฎหมาย & $P$ & 12 \\
\hline 26 & $\begin{array}{l}\text { พนักงานของบริษัทผู้รับเหมาไม่ปฏิบัติตามระเบียบขั้นตอนการปฏิบัติงาน } \\
\text { (Procedure) }\end{array}$ & $P$ & 12 \\
\hline 27 & $\begin{array}{l}\text { หน่วยงานจัดซื้อ จัดจ้างขาดการติดต่อประสานงานกับผู้ขาย (Vendor) อย่าง } \\
\text { ต่อเนื่อง }\end{array}$ & $P$ & 12 \\
\hline 28 & ผู้ขาย (Vendor) ส่งสินค้ามาไม่ตรงกับใบสั่งซื้อ (Purchase Order) & $P$ & 12 \\
\hline
\end{tabular}

\section{2. การวิเคราะห์ด้วยแผนผังเหตุ และผล (Cause and Effect Diagram)}

การวิเคราะห์หาปัจจัย หรือสาเหตุที่แท้จริงยังคงเป็นสิ่งจำเป็น เนื่องจากว่ารายการปัญหาที่เกิดขึ้นไม่สามารถระบุได้ว่าการ สื่อสารผิดพลาดอย่างไร และผิดพลาดจากใคร ซึ่งงานวิจัยนี้ได้ใช้เทคนิคการวิเคราะห์ด้วยแผนผังเหตุ และผล (Cause and Effect Diagram) หรือที่ถูกเรียกว่าผังก้างปลา โดยเป็นวิธีการระดมสมอง (Brainstorming) และแสดงความคิดเห็นจากผู้มี ประสบการณ์ในการทำงานโครงการ ดังนั้นปัญหาการสื่อสารที่มีคะแนนความเสี่ยงอยู่ในระดับสูงทั้ง 28 รายการจะถูกนำมา วิเคราะห์ด้วยเทคนิคนี้เพื่อหาแนวทางการแก้ไขด้วยการพัฒนาระบบการสื่อสาร ตัวอย่างการวิเคราะห์ปัญหาลำดับที่ 7 จาก 
ตารางที่ 7 คือ หน่วยงานวิศวกรรมส่งรายละเอียดของแบบงานไม่ชัดเจน หรือไม่ครบถ้วนให้กับหน่วยงานจัดซื้อ จัดจ้าง สามารถอธิบายได้ดังรูปที่ 2 สำหรับสาเหตุหลักที่เลือกนำไปแก้ไขคือ ขาดการประสานงานภายในหน่วยงานวิศวกรรม และ ขาดการประชุมร่วมกับทุกฝ่าย

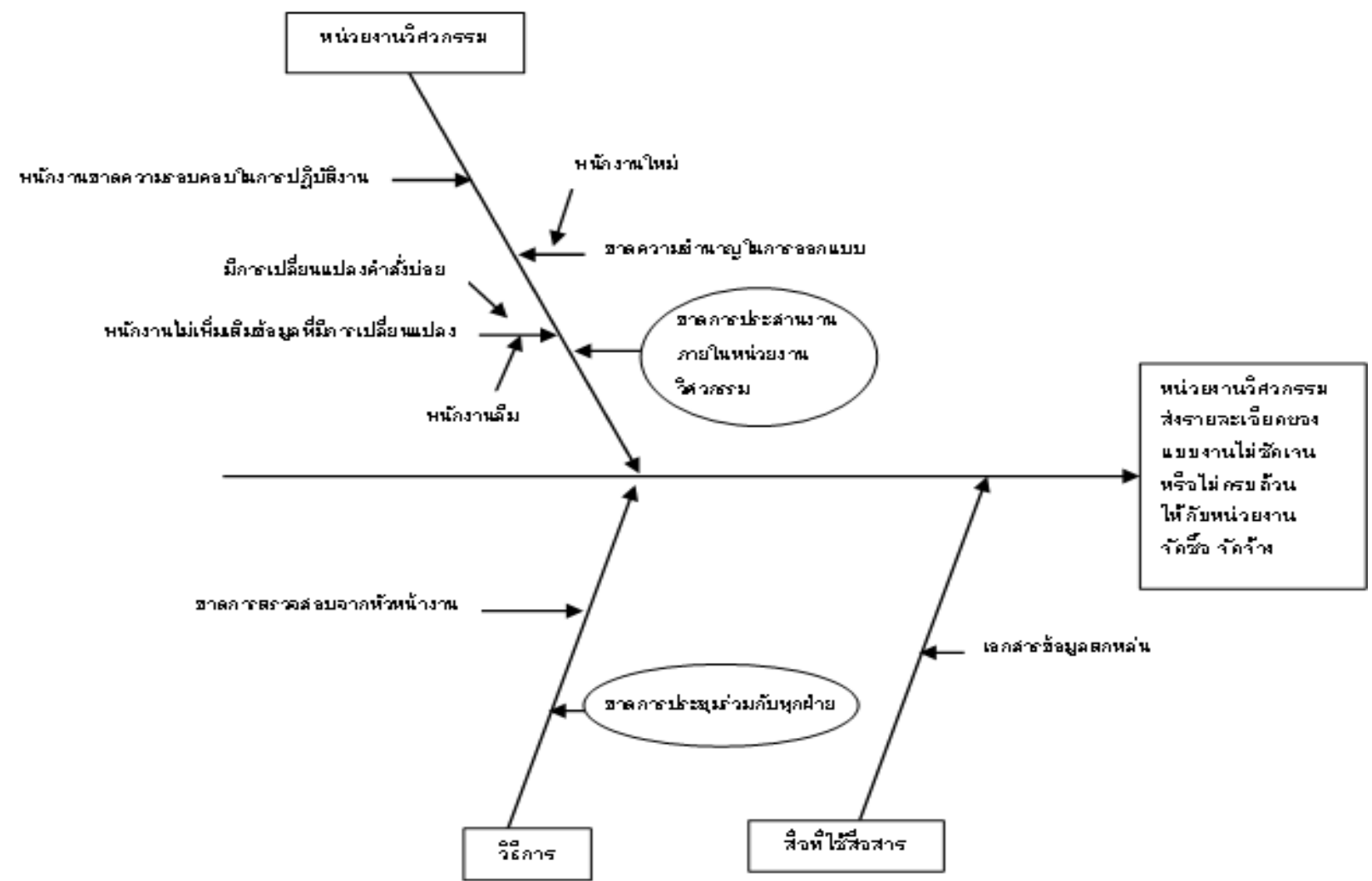

รูปที่ 2 ตัวอย่างการวิเคราะห์ปัญหาการสื่อสารด้วยแผนผังก้างปลา

\section{3. รูปแบบของระบบการสื่อสารที่พัฒนาขึ้น}

ระบบการสื่อสารที่พัฒนาขึ้นจะเปรียบเสมือนแผนการสื่อสารในการดำเนินงานโครงการอีพีซีของบริษัทกรณีศึกษา ซึ่งจะ จัดทำอยู่ในรูปแบบของตาราง และแบ่งเป็นกลุ่มการสื่อสารที่เกี่ยวข้องในงานโครงการด้านวิศวกรรม การจัดซื้อ จัดจ้าง และ การก่อสร้าง ซึ่งข้อมูลในคอลัมน์ของตารางคือ องค์ประกอบของการติดต่อสื่อสาร ประกอบด้วย ชื่อเรื่องการสื่อสาร (Communicated Information) คือ กิจกรรมในการสื่อสาร ซึ่งแสดงเป็นขั้นตอนของการสื่อสารตั้งแต่ช่วงที่เริ่มการดำเนินงาน ด้านวิศวกรรม, งานจัดซื้อ จัดจ้าง และงานก่อสร้าง อาทิเช่น การทบทวนสัญญา เป็นต้น จุดประสงค์การสื่อสาร (Objective) คือ การแสดงความต้องการ หรือประโยชน์ของการสื่อสารในกิจกรรมการสื่อสารนั้น เพื่อให้พนักงานในทีมงานโครงการ สามารถคาดหวังถึงผลลัพธ์ที่ได้จากการสื่อสารหลังจากกิจกรรมการสื่อสารนั้นเสร็จสิ้น อาทิเช่น เพิ่มความเข้าใจให้กับ ทีมงานโครงการเกี่ยวกับคุณลักษณะงาน ช่องทางการสื่อสาร (Communication Channels) คือ การแสดงช่องทางการ สื่อสารที่มีความเหมาะสมสำหรับกิจกรรมของการสื่อสารนั้น โดยช่องทางการสื่อสารของระบบการสื่อสารที่พัฒนาขึ้น จะไม่ กล่าวถึงวิธีการสื่อสารผ่านทางโทรศัพท์ ซึ่งประกอบด้วย การประชุม (Meeting) ใบนำส่งเอกสาร (Document Transmittal) อีเมล์ (E-mail) จดหมาย (Letter) รายงาน (Report) หัวข้อหรือข่าวสารในการสื่อสาร (Contents/Agenda) คือ การกำหนด หัวข้อ หรือเรื่องที่ต้องการสื่อสาร ซึ่งเป็นการวางแผนการสื่อสารเพื่อให้บรรลุวัตถุประสงค์ในการสื่อสารของกิจกรรมการ สื่อสารนั้นๆ ผู้ส่งสาร (Sender) คือ บุคคล กลุ่มบุคคล หรือหน่วยงานที่ทำหน้าที่ส่งข้อมูล หรือข่าวสารไปยังผู้รับสารโดยผ่าน 
ช่องทางการสื่อสารต่างๆ ผู้รับสาร (Receiver) คือ บุคคล กลุ่มบุคคล หรือหน่วยงานที่รับข้อมูล หรือข่าวสารจากผู้สงสารผ่าน ช่องทางการสื่อสารต่างๆ และเงื่อนไขการสื่อสาร (Conditions) คือ การอธิบายรายละเอียดเพิ่มเติมสำหรับบางเรื่องการ สื่อสาร อาจเป็นข้อแนะนำในการสื่อสาร อาทิเช่น แนะนำช่องทางการสื่อสารที่เหมาะสมที่สุด และความถี่ของการสื่อสารที่ เหมาะสม เป็นต้น แสดงได้ดังตารางที่ 8

\section{4. การพัฒนาระบบการสื่อสารจากปัญหาการสื่อสาร}

จากการวิเคราะห์ปัญหาการสื่อสารทั้ง 28 รายการ ด้วยแผนผังก้างปลา ทำให้ทราบสาเหตุ หรือปัจจัยที่แท้จริงในแต่ละ ปัญหา ซึ่งจะเลือกพิจารณาเฉพาะสาเหตุที่มีความเป็นไปได้ในการแก้ไข สำหรับการสร้างระบบการสื่อสารเพื่อแก้ไขปัญหา การสื่อสารของงานวิจัยนี้ได้มีการนำปัญหามาจัดเป็นหมวดหมู่ตามกลุ่มการประสานงาน และเสนอแนวทางการแก้ไขของ ปัญหาในแต่ละกลุ่มการประสานงาน โดยข้อมูลแนวทางการแก้ไขที่เสนอจะถูกนำไปใส่ลงในรูปแบบของระบบการสื่อสาร ตัวอย่างการนำเสนอแนวทางแก้ไขผ่านระบบการสื่อสารสามารถแสดงได้ดังตารางที่ 9

นอกจากการเสนอแนวทางแก้ไขในตารางที่ 8 งานวิจัยนี้ได้มีการเพิ่มเติมหัวข้อหลัก ซึ่งประกอบด้วย ชื่อเรื่องการสื่อสาร จุดประสงค์การสื่อสาร และเงื่อนไขการสื่อสารเพื่อให้เป็นไปตามรูปแบบของระบบการสื่อสารที่ออกแบบไว้ โดยที่ชื่อเรื่องการ สื่อสารถูกสร้างขึ้นมาจากการจัดกลุ่มของหัวข้อหรื่อข่าวสารที่จำเป็นในการสื่อสาร และมีการเรียงตามลำดับการเกิดขึ้น ก่อนหลังของกิจกรรมในการดำเนินงานโครงการอีพีซี ซึ่งจากการจัดกลุ่มของหัวข้อที่จำเป็นในการสื่อสารดังกล่าว สามารถ นำมาตั้งชื่อเรื่องการสื่อสารได้ว่า การตรวจสอบแบบงานทางวิศวกรรมในแต่ละกลุ่มงาน (Interdisciplinary Checking) สำหรับจุดประสงค์การสื่อสารตามหัวข้อที่จำเป็นในการสื่อสารดังกล่าว คือ 1 .ช่วยลดปัญหาในการติดต่อหรือประสานงาน ตามที่วิศวกรในแต่ละกลุ่มงานได้เห็นคำวิจารณ์ หรือข้อคิดเห็นของวิศวกรคนอื่นๆ และ 2 .ทบทวน และประสานงานเพื่อแก้ไข ปัญหาที่อาจเกิดขึ้นจากคำวิจารณ์หรือข้อคิดเห็นของวิศวกรคนอื่นๆ โดยกิจกรรมการสื่อสารนี้บางครั้งผู้จัดการโครงการอาจ เข้าร่วมรับฟังปัญหาได้ตามความเหมาะสม ซึ่งข้อมูลส่วนนี้จะจัดอยู่ในเงื่อนไขของการสื่อสาร สำหรับตัวอย่างระบบการ สื่อสารที่พัฒนาขึ้นจากปัญหาการสื่อสาร 2 รายการของตารางที่ 9 สามารถนำมาแสดงใหม่ได้ดังตารางที่ 10 


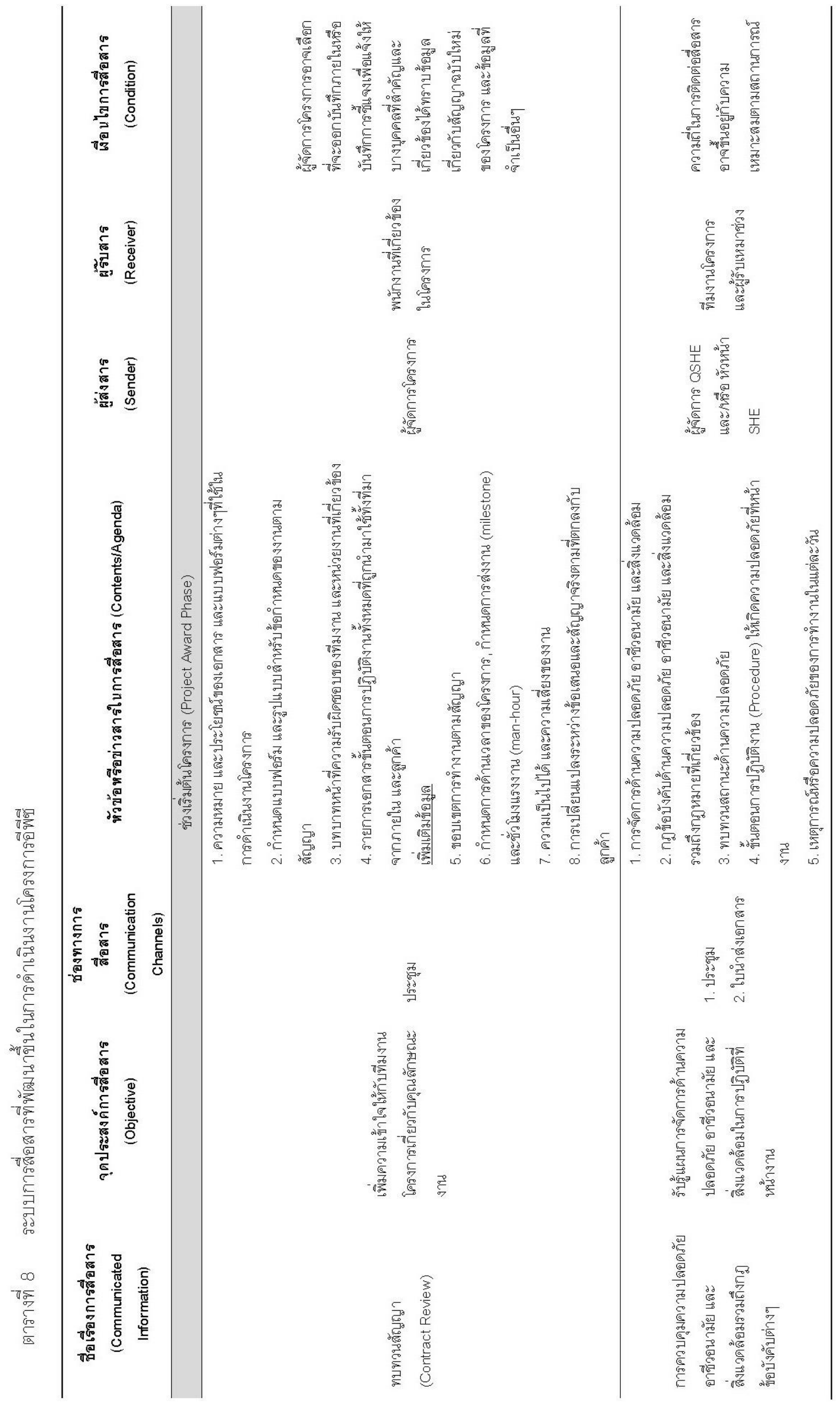




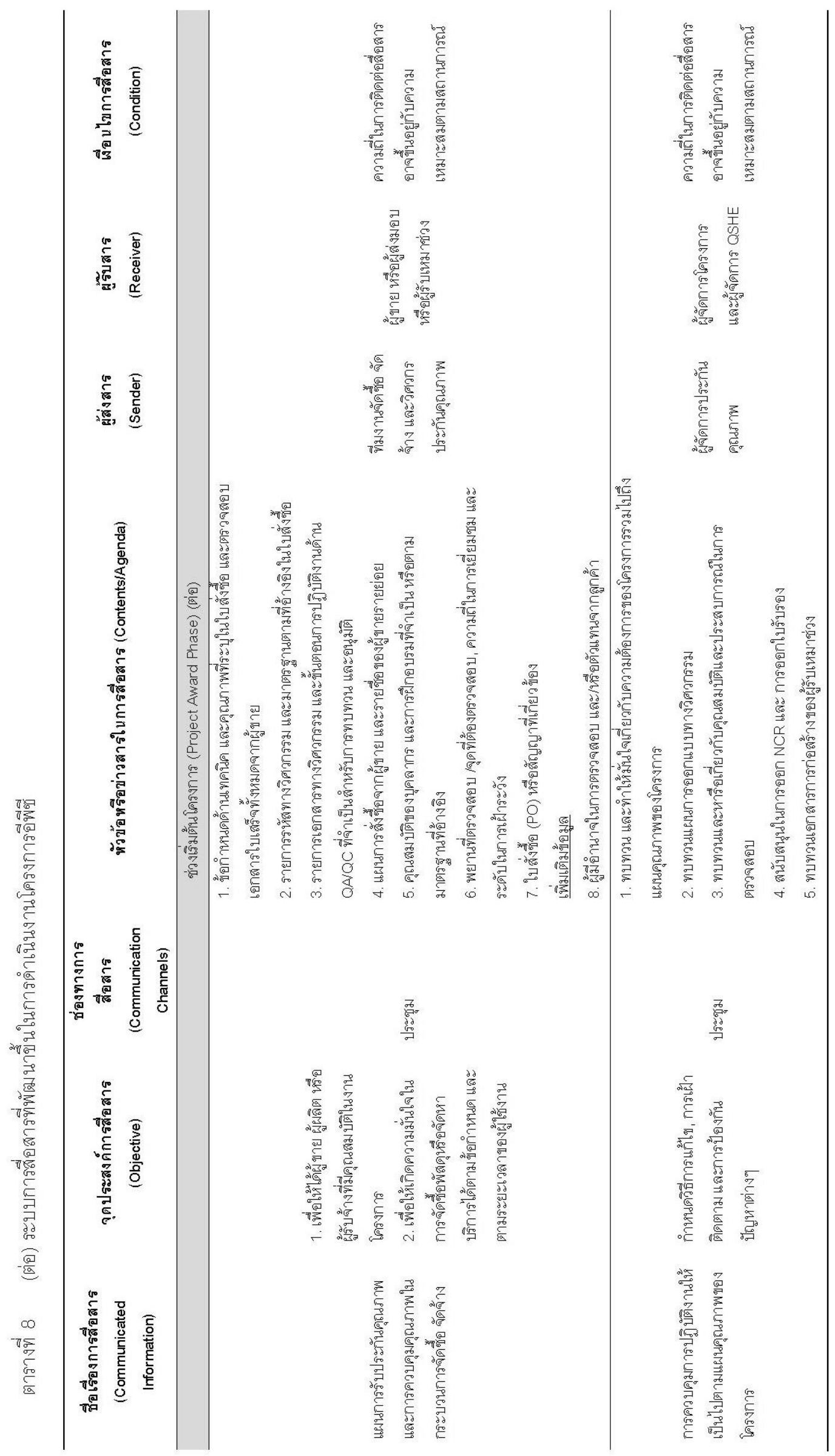

วารสารวิศวกรรมศาสตร์ ปีที่ 4 ฉบับที่ 4, ISSN 1906-3636 (http://www.ej.eng.chula.ac.th/) 


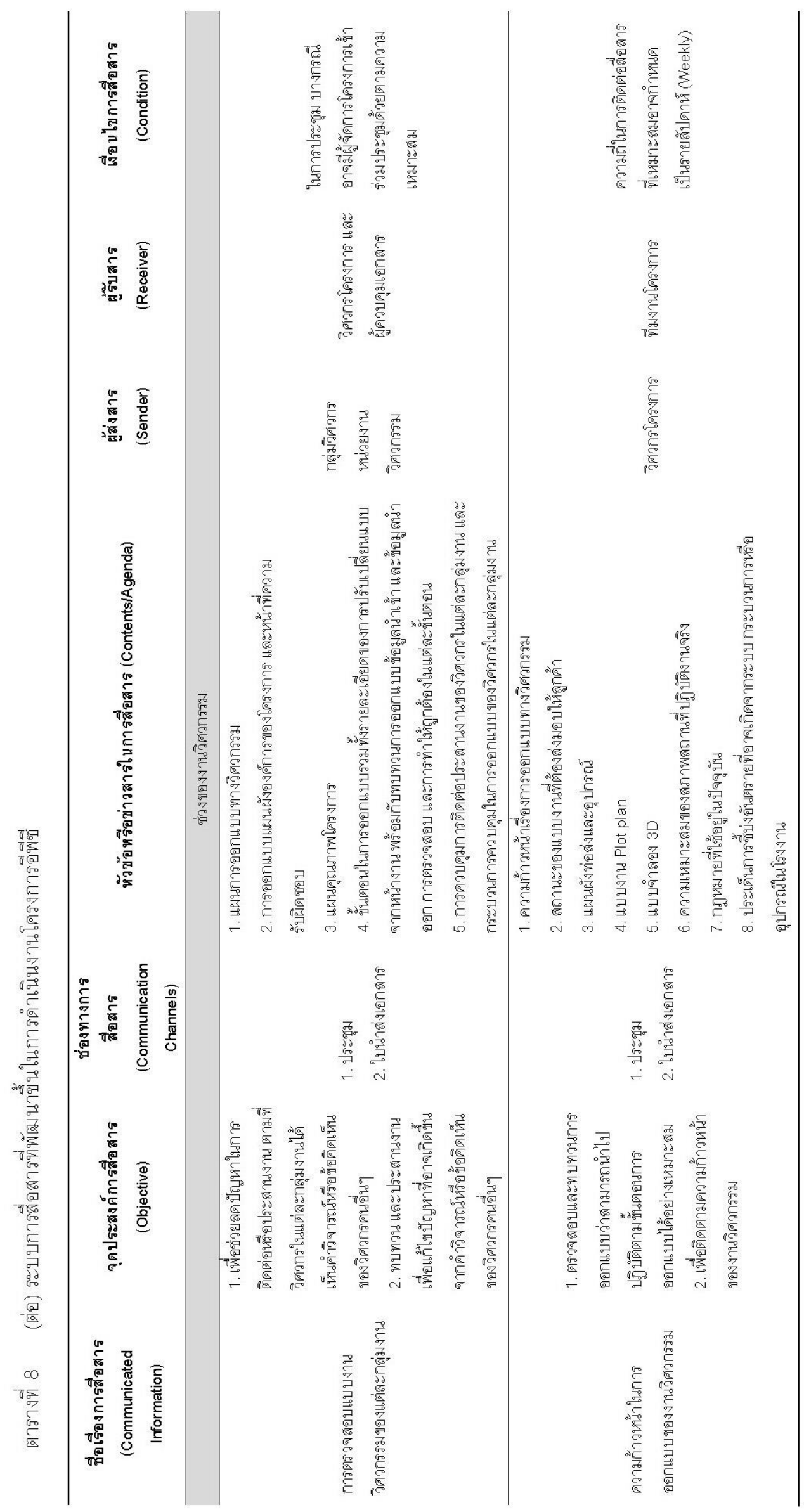




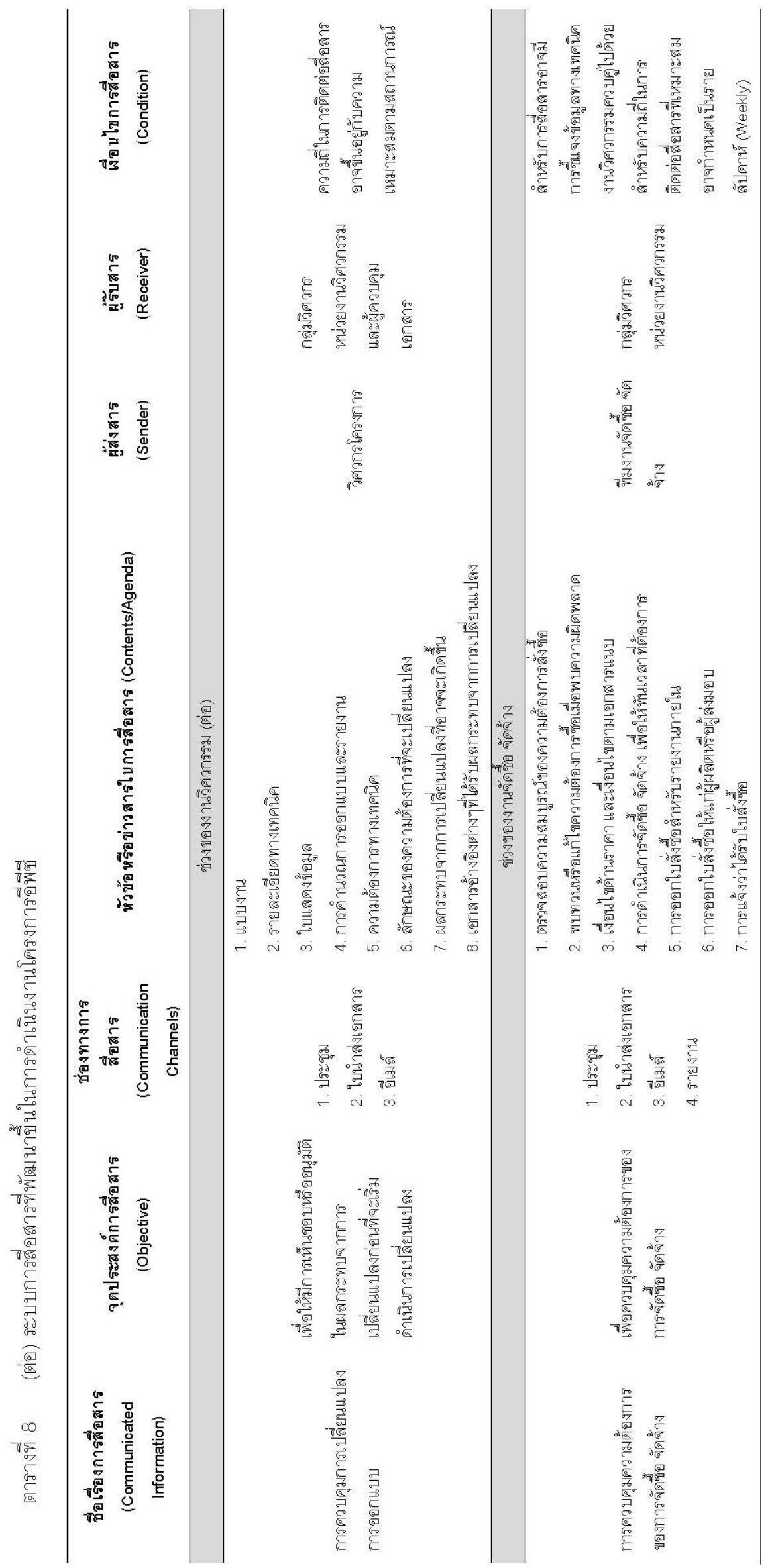




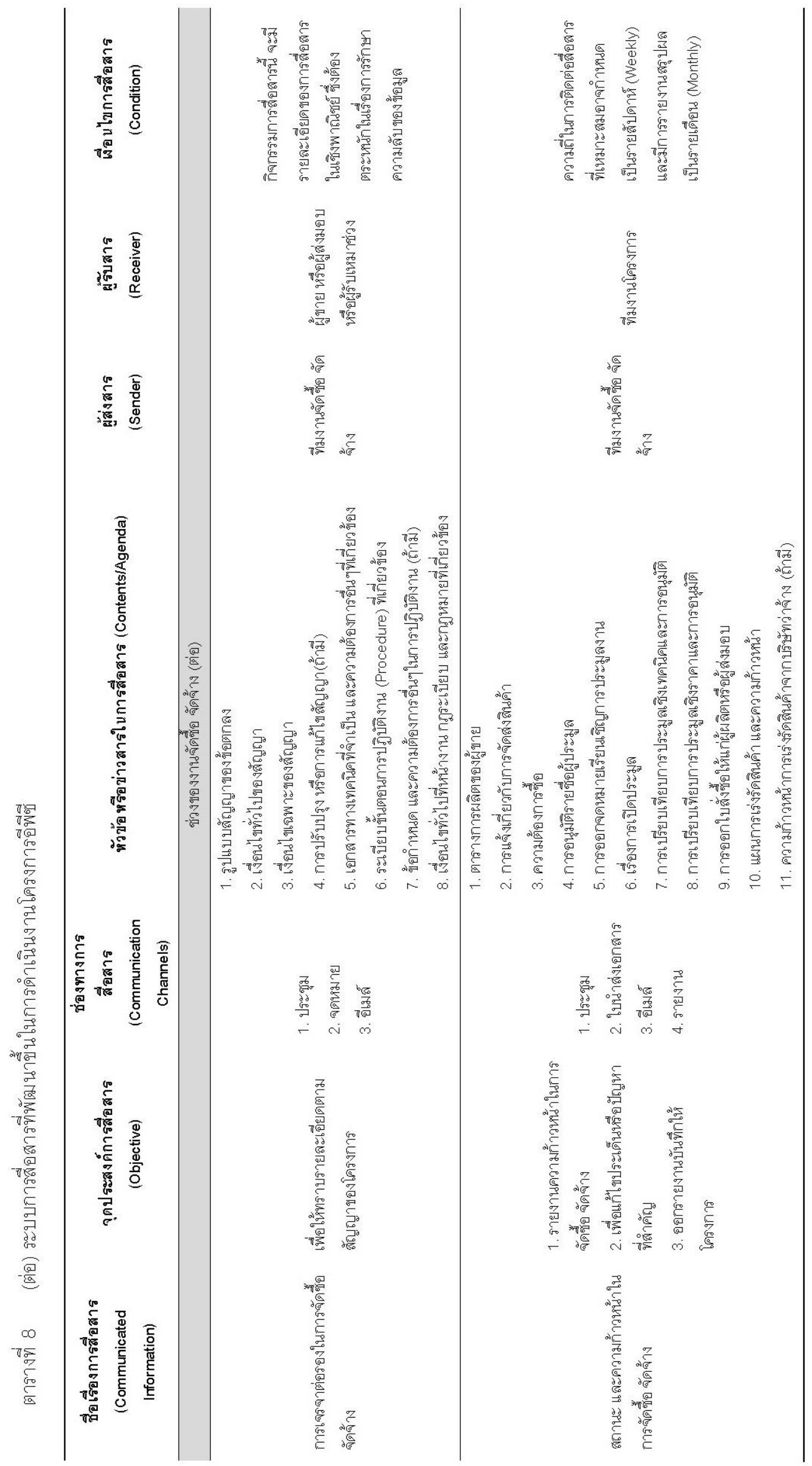




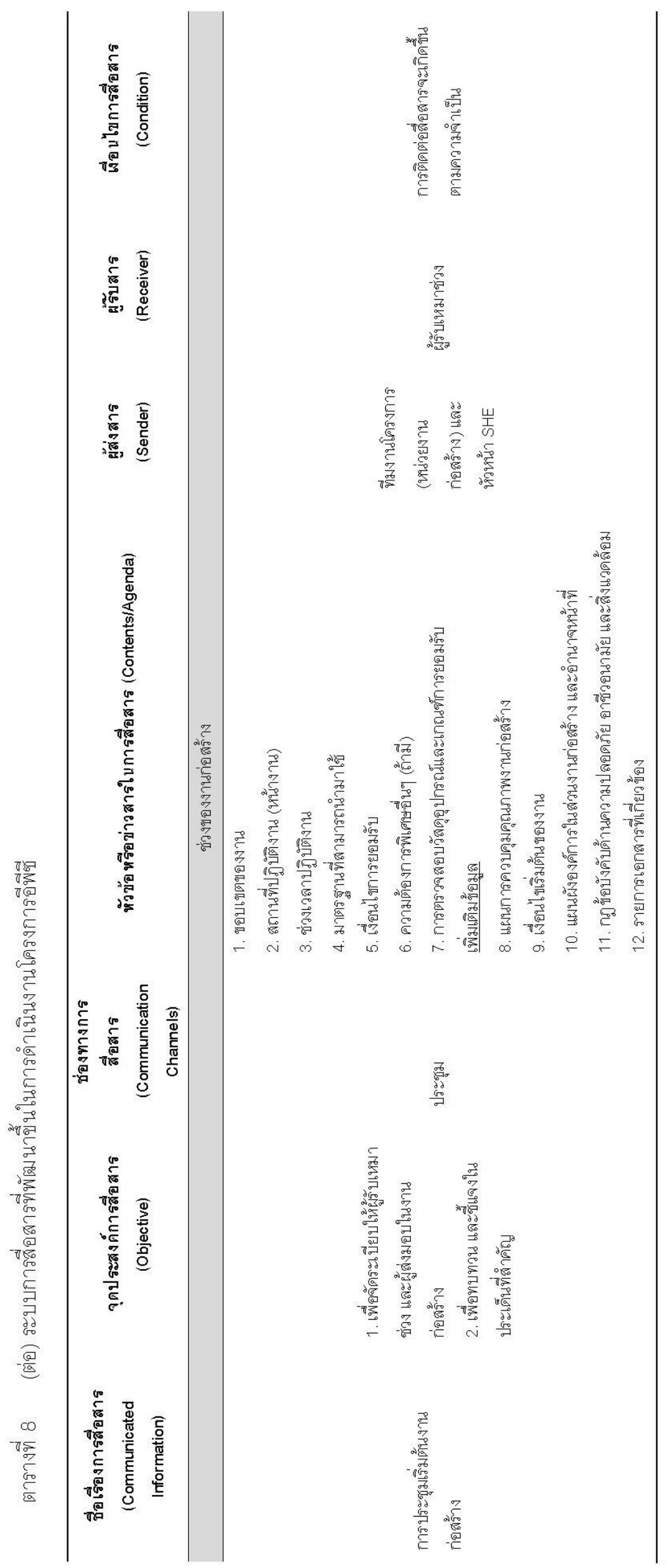


ตารางที่ 9 ตัวอย่างการนำเสนอแนวทางแก้ไขผ่านระบบการสื่อสาร

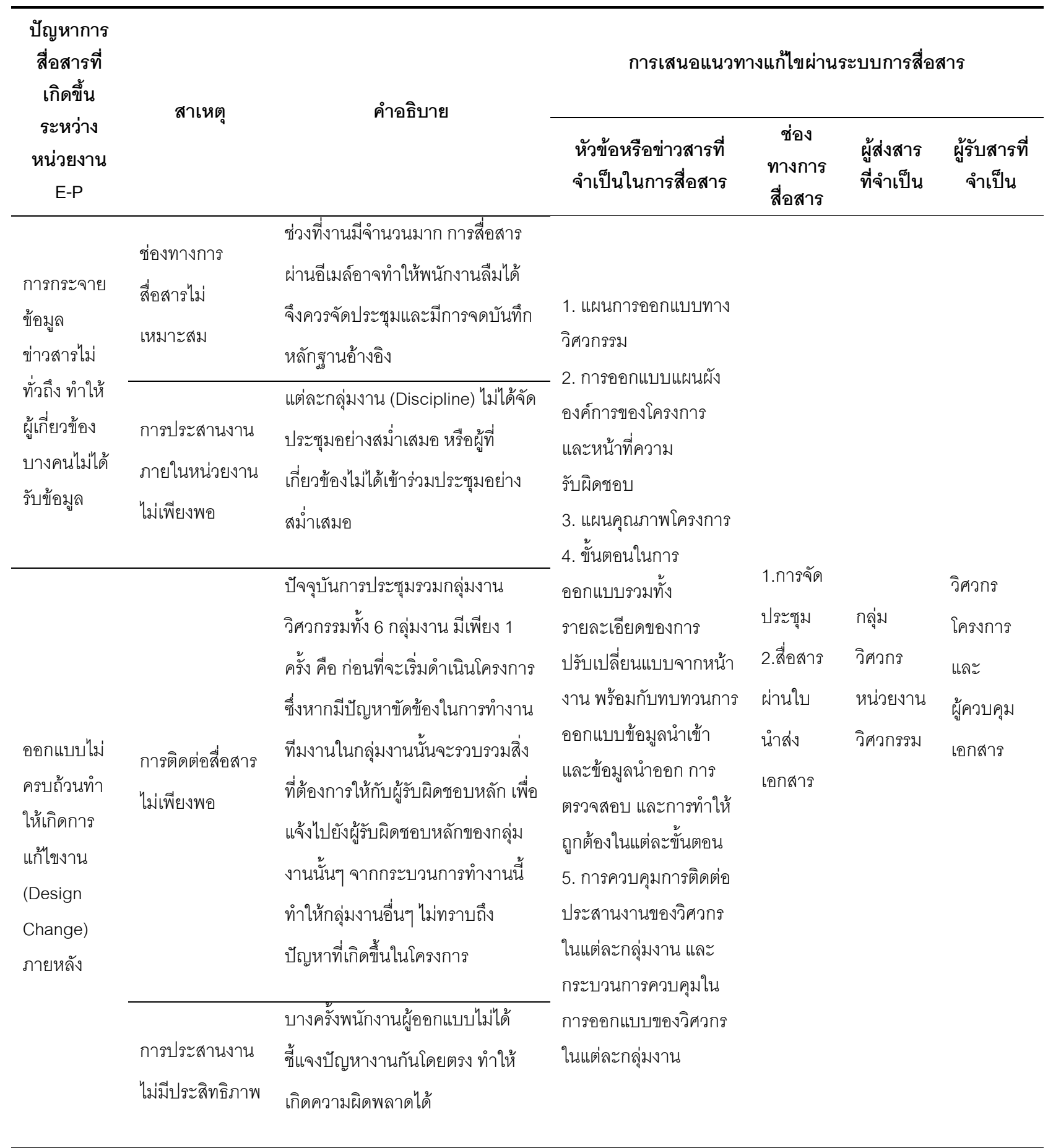


ตารางที่ 10 ตัวอย่างระบบการสื่อสารที่พัฒนาขึ้นเพื่อใช้ในการดำเนินงานโครงการอีพีซี

\begin{tabular}{|c|c|c|c|c|c|c|}
\hline $\begin{array}{l}\text { ชื่อเรื่องการ } \\
\text { สื่อสาร }\end{array}$ & $\begin{array}{l}\text { จุดประสงค์การ } \\
\text { สื่อสาร }\end{array}$ & $\begin{array}{l}\text { ช่องทางการ } \\
\text { สื่อสาร }\end{array}$ & $\begin{array}{c}\text { หัวข้อหรือข่าวสารในการ } \\
\text { สื่อสาร }\end{array}$ & ผู้ส่งสาร & ผู้รับสาร & เงื่อนไข \\
\hline $\begin{array}{l}\text { การตรวจสอบ } \\
\text { แบบงานทาง } \\
\text { วิศวกรรมใน } \\
\text { แต่ละกลุ่มงาน }\end{array}$ & $\begin{array}{l}\text { 1.เพื่อช่วยลดปัญหาใน } \\
\text { การติดต่อหรือ } \\
\text { ประสานงาน ตามที่ } \\
\text { วิศวกรในแต่ละกลุ่ม } \\
\text { งานได้เห็นคำวิจารณ์ } \\
\text { หรือข้อคิดเห็นของ } \\
\text { วิศวกรคนอื่นๆ } \\
\text { 2.ทบทวน และ } \\
\text { ประสานงานเพื่อแก้ไข } \\
\text { ปัญหาที่อาจเกิดขึ้น } \\
\text { จากคำวิจารณ์หรือ } \\
\text { ข้อคิดเห็นของวิศวกร } \\
\text { คนอื่นๆ }\end{array}$ & $\begin{array}{l}\text { 1.การจัดประชุม } \\
\text { 2.สื่อสารผ่านใบ } \\
\text { นำส่งเอกสาร }\end{array}$ & $\begin{array}{l}\text { 1.แผนการออกแบบทางวิศวกรรม } \\
\text { 2.การออกแบบแผนผังองค์การ } \\
\text { ของโครงการ และหน้าที่ความ } \\
\text { รับผิดชอบ } \\
\text { 3.แผนคุณภาพโครงการ } \\
\text { 4.ขั้นตอนในการออกแบบรวมทั้ง } \\
\text { รายละเอียดของการปรับเปลี่ยน } \\
\text { แบบจากหน้างาน พร้อมกับ } \\
\text { ทบทวนการออกแบบข้อมูลนำเข้า } \\
\text { และข้อมูลนำออก การตรวจสอบ } \\
\text { และการทำให้ถูกต้องในแต่ละ } \\
\text { ขั้นตอน } \\
\text { 5.การควบคุมการติดต่อ } \\
\text { ประสานงานของวิศวกรในแต่ละ } \\
\text { กลุ่มงาน และกระบวนการ } \\
\text { ควบคุมในการออกแบบของ } \\
\text { วิศวกรในแต่ละกลุ่มงาน }\end{array}$ & $\begin{array}{l}\text { กลุ่มวิศวกร } \\
\text { หน่วยงาน } \\
\text { วิศวกรรม }\end{array}$ & $\begin{array}{l}\text { วิศวกร } \\
\text { โครงการ } \\
\text { และ } \\
\text { ผู้ควบคุม } \\
\text { เอกสาร }\end{array}$ & $\begin{array}{l}\text { ในการประสุม } \\
\text { บางกรณีอาจมี } \\
\text { ผู้จัดการโครงการ } \\
\text { เข้าร่วมประชุม } \\
\text { ด้วยตามความ } \\
\text { เหมาะสม }\end{array}$ \\
\hline
\end{tabular}

\section{6. การประยุกต์ใช้ระบบการสื่อสารที่พัฒนาขึ้นในโครงการอีพีซี}

การประยุกต์ใช้ระบบการสื่อสารที่พัฒนาขึ้นในงานโครงการอีพีซีสามารถทำได้โดยการนำระบบการสื่อสารที่พัฒนาขึ้นไป เป็นระเบียบขั้นตอนการปฏิบัติงาน (Procedure) ของพนักงานในทีมงานโครงการอีพีซี เพื่อต้องการพิสูจน์ว่าระบบการ สื่อสารที่พัฒนาขึ้นนี้สามารถลดความเสี่ยงของการเกิดปัญหา และช่วยเพิ่มประสิทธิภาพด้านการสื่อสารได้จริงหรือไม่

\section{1. ข้อมูลทั่วไปของโครงการอีพีซีทดสอบ}

โครงการอีพีซีทดสอบของงานวิจัยนี้ คือ โครงการอีพีซีที่กำลังอยู่ระหว่างการดำเนินงาน ซึ่งมีรายละเอียดดังนี้คือ

- ชื่อโครงการ By Products Value (เป็นชื่อย่อโครงการ)

- โครงการมีวัตถุประสงค์เพื่อออกแบบ ก่อสร้าง และติดตั้ง Offsite BD Pipelines, Storage Tanks และ Facilities โดยใช้ งบประมาณ $86,200,000$ บาท ภายในระยะเวลา 25 เดือน ตั้งแต่เดือนกันยายน พ.ศ. 2554 ถึง เดือนกันยายน พ.ศ. 2556 
- เป็นโครงการที่ประกอบด้วย 3 ลักษณะงานหลัก คือ งานวิศวกรรมโดยมีสัดส่วนของงานซึ่งคิดเป็นเปอร์เซ็นต์เท่ากับ $8.5 \%$ งานจัดซื้อ จัดจ้างมีสัดส่วนของงานเท่ากับ $45 \%$ และงานก่อสร้างมีสัดส่วนของงานเท่ากับ $45 \%$

\section{2. ปัญหาการสื่อสารที่เกิดขึ้นในโครงการอีพีซีทดสอบ}

งานวิจัยนี้ได้ศึกษาปัญหาการสื่อสารที่เกิดขึ้นในโครงการอีพีซีทดสอบที่ผ่านมา โดยทบทวนเอกสารหรือหลักฐานจากบันทึก การประชุมรายสัปดาห์ (Minutes of Meeting) รายงานโครงการประจำเดือน (Monthly Report) และมีการสอบถามข้อมูล จากผู้จัดการโครงการ และวิศวกรผู้ปฏิบัติงานในทีมงานโครงการ สำหรับปัญหาการสื่อสารที่เกิดขึ้นในโครงการอีพีซีทดสอบ พบว่ามีจำนวนทั้งสิ้น 19 รายการ ซึ่งล้วนเป็นปัญหาที่เคยเกิดขึ้นใน 5 โครงการกรณีศึกษาดังกล่าว แสดงได้ดังตารางที่ 11

\section{3. ผลของการประยุกต์ใช้ระบบการสื่อสารที่พัฒนาขึ้นในโครงการอีพีซีทดสอบ} ก่อนการนำระบบการสื่อสารที่พัฒนาขึ้นไปใช้ได้มีการประเมินความเสี่ยงของปัญหาการสื่อสารที่เกิดขึ้นในโครงการอีพีซี ทดสอบ ซึ่งพบว่ามีปัญหาการสื่อสารที่มีคะแนนความเสี่ยงสูง จำนวนทั้งหมด 16 รายการ และหลังจากที่มีการนำระบบการ สื่อสารที่พัฒนาขึ้นไปเป็นระเบียบขั้นตอนการปฏิบัติงาน (Procedure) ของพนักงานในที่มโครงการอีพีซีทดสอบ เป็น ระยะเวลา 3 เดือน ซึ่งได้ประเมินความเสี่ยงของปัญหาอีกครั้ง และพบว่าคะแนนความเสี่ยงของปัญหาการสื่อสารดังกล่าวมี ค่าที่ลดลงจนอยู่ในระดับที่สามารถยอมรับได้ โดยเหลือเพียง 2 ปัญหาเท่านั้นที่คะแนนความเสี่ยงยังคงอยู่ในระดับสูง คือ การกระจายข้อมูลเกี่ยวกับการเปลี่ยนแปลงรายละเอียดงานจากลูกค้าไม่ทั่วถึง และพนักงานของบริษัทผู้รับเหมาไม่ปฏิบัติ ตามระเบียบขั้นตอนการปฏิบัติงาน (Procedure) ดังตารางที่ 12

\section{7. สรุปผลการวิจัย และข้อเสนอแนะ}

\section{1. สรุปผลการวิจัย}

จากการนำระบบการสื่อสารที่พัฒนาขึ้นไปประยุกต์ใช้ในการดำเนินงานโครงการอีพีซี พบว่าพนักงานในทีมโครงการมีความ ตระหนัก และให้ความสำคัญในการสื่อสารมากขึ้น ส่งผลให้คะแนนความเสี่ยงของปัญหาการสื่อสารที่เคยอยู่ในระดับสูง คือ มีคะแนนความเสี่ยงตั้งแต่ 10 ถึง 16 คะแนน มีค่าที่ลดลง เนื่องมาจากอัตราการเกิดปัญหา หรือความถี่ของการเกิดปัญหา การสื่อสารนั้นมีค่าลดลง โดยเหลือเพียง 2 ปัญหาเท่านั้นที่คะแนนความเสี่ยงยังคงมีระดับความรุนแรงอยู่ในระดับสูง คือ การกระจายข้อมูลเกี่ยวกับการเปลี่ยนแปลงรายละเอียดงานจากลูกค้าไม่ทั่วถึง และพนักงานของบริษัทผู้รับเหมาไม่ปฏิบัติ ตามระเบียบขั้นตอนการปฏิบัติงาน (Procedure) ดังนั้นสรุปได้ว่าระบบการสื่อสารที่พัฒนาขึ้นนี้สามารถทำให้ความเสี่ยง ของปัญหาการสื่อสารโดยส่วนใหญ่ที่มีค่าระดับความรุนแรงสูงมีค่าที่ลดลงจนอยู่ในระดับที่สามารถยอมรับได้ และมี ประสิทธิภาพถึง 87 เปอร์เซ็นต์ 
ตารางที่ 11 รายการปัญหาการสื่อสารที่เกิดขึ้นในโครงการอีพีซีทดสอบ

ลำดับ รายการปัญหาการสื่อสาร

เกี่ยวข้องระหว่าง

หน่วยงาน

1 หน่วยงานวิศวกรรม ส่ง รายละเอียดของแบบงานไม่ชัดเจนหรือไม่ครบถ้วนให้กับหน่วยงาน

E-P จัดซื้อ จัดจ้าง

2 แบบงานที่ส่งให้หน่วยงานจัดซื้อ จัดจ้างเพื่อทำการสั่งซื้อ ไม่ได้อัพเดตข้อมูลล่าสุด E-P

3 หน่วยงานจัดซื้อ จัดจ้างสั่งซื้อสินค้าผิดสเปคจากแบบงาน $E-P$

4 เอกสารเรียกร้องการสั่งซื้อ (Requisition) ของหน่วยงานวิศวกรรมไม่สมบูรณ์ $E-P$

5 หน่วยงานก่อสร้างได้รับแบบงานที่มีสถานะก่อสร้างได้ (Drawing for Construction) ล่าช้า $E-C$ กว่ากำหนด

6 แบบงานที่มีสถานะก่อสร้างได้ (Drawing for Construction) ไม่ได้อัพเดตข้อมูลล่าสุด E-C

7 แบบงานไม่เหมาะสม หรือไม่สามารถนำไปใช้งานได้จริงและต้องมีการแก้ไข $\mathrm{E}-\mathrm{C}$

8 ขาดการประสานงานทำให้การก่อสร้างผิดจากแบบงาน $E-C$

9 หน่วยงานก่อสร้างได้รับวัสดุหรืออุปกรณ์ล่าช้ากว่ากำหนด หรือการจ้างผู้รับเหมา ล่าช้ากว่า $\quad C-P$ กำหนด

10 ปัญหาการเลือกผู้รับเหมาที่ไม่มีประสิทธิภาพมาทำงาน $\quad$ C-P

11 อุปกรณ์ที่ใช้ในการก่อสร้างของผู้รับเหมาไม่ผ่านเกณฑ์ความปลอดภัย $\quad C-P$

12 พนักงานของบริษัทผู้รับเหมาไม่สามารถเข้าทำงานได้เนื่องจากไม่ปฏิบัติตามกฎระเบียบ C-P ของบริษัท หรือกฎหมาย

13 พนักงานใหม่ในที่มงานโครงการยังไม่ทราบระเบียบขั้นตอนการปฏิบัติงาน (Procedure) ที่ $\quad$ E-P-C เกี่ยวข้องในงาน

14 การกระจายข้อมูลเกี่ยวกับการเปลี่ยนแปลงรายละเอียดงานจากลูกค้าไม่ทั่วถึง $E$

15 ขาดการติดต่อประสานงานระหว่างกลุ่มงานในหน่วยงานวิศวกรรม (Discipline) ทำให้เกิด $E$ การแก้ไขแบบงาน

16 ออกแบบไม่ครบถ้วนทำให้เกิดการแก้ไขงาน (Design Change) ภายหลัง $E$

17 ลูกค้าให้ข้อมูลรายละเอียดโครงการล่าช้า $E$

18 พนักงานของบริษัทผู้รับเหมาไม่ปฏิบัติตามระเบียบขั้นตอนการปฏิบัติงาน (Procedure) P

19 ผู้ขาย (Vendor) ส่งสินค้ามาไม่ตรงกับใบสั่งซื้อ (Purchase Order) P 
ตารางที่ 12 ผลของระดับความรุนแรงก่อนและหลังการนำระบบการสื่อสารที่พัฒนาขึ้นไปใช้

\begin{tabular}{|c|c|c|c|}
\hline \multirow[b]{2}{*}{ ลำดับ } & \multirow[b]{2}{*}{ ปัญหาการสื่อสารในโครงการอีพีซีทดสอบที่มีระดับความเสี่ยงสูง } & \multicolumn{2}{|c|}{ คะแนนความเสี่ยง } \\
\hline & & $\begin{array}{l}\text { ก่อนนำระบบ } \\
\text { ไปใช้ }\end{array}$ & $\begin{array}{l}\text { หลังนำระบบ } \\
\text { ไปใช้ }\end{array}$ \\
\hline 1 & $\begin{array}{l}\text { แบบงานที่ส่งให้หน่วยงานจัดซื้อ จัดจ้างเพื่อทำการสั่งซื้อ ไม่ได้อัพเดตข้อมูล } \\
\text { ล่าสุด }\end{array}$ & 16 & 8 \\
\hline 2 & $\begin{array}{l}\text { หน่วยงานก่อสร้างได้รับแบบงานที่มีสถานะก่อสร้างได้ (Drawing for } \\
\text { Construction) ล่าช้ากว่ากำหนด }\end{array}$ & 16 & 8 \\
\hline 3 & $\begin{array}{l}\text { แบบงานที่มีสถานะก่อสร้างได้ (Drawing for Construction) ไม่ได้อัพเดต } \\
\text { ข้อมูลล่าสุด }\end{array}$ & 16 & 8 \\
\hline 4 & $\begin{array}{l}\text { การกระจายข้อมูลเกี่ยวกับการเปลี่ยนแปลงรายละเอียดงานจากลูกค้าไม่ } \\
\text { ทั่วถึง }\end{array}$ & 16 & 12 \\
\hline 5 & $\begin{array}{l}\text { ขาดการติดต่อประสานงานระหว่างกลุ่มงานในหน่วยงานวิศวกรรม } \\
\text { (Discipline) ทำให้เกิดการแก้ไขแบบงาน }\end{array}$ & 16 & 8 \\
\hline 6 & $\begin{array}{l}\text { หน่วยงานวิศวกรรม ส่ง รายละเอียดของแบบงานไม่ชัดเจนหรือไม่ครบถ้วน } \\
\text { ให้กับหน่วยงานจัดซื้อ จัดจ้าง }\end{array}$ & 12 & 8 \\
\hline 7 & หน่วยงานจัดซื้อ จัดจ้างสั่งซื้อสินค้าผิดสเปคจากแบบงาน & 12 & 6 \\
\hline 8 & แบบงานไม่เหมาะสม หรือไม่สามารถนำไปใช้งานได้จริงและต้องมีการแก้ไข & 12 & 9 \\
\hline 9 & $\begin{array}{l}\text { หน่วยงานก่อสร้างได้รับวัสดุหรืออุปกรณ์ล่าช้ากว่ากำหนด หรือการจ้าง } \\
\text { ผู้รับเหมา ล่าช้ากว่ากำหนด }\end{array}$ & 12 & 9 \\
\hline 10 & ปัญหาการเลือกผู้รับเหมาที่ไม่มีประสิทธิภาพมาทำงาน & 12 & 8 \\
\hline 11 & อุปกรณ์ที่ใช้ในการก่อสร้างของผู้รับเหมาไม่ผ่านเกณฑ์ความปลอดภัย & 12 & 6 \\
\hline 12 & $\begin{array}{l}\text { พนักงานของบริษัทผู้รับเหมาไม่สามารถเข้าทำงานได้เนื่องจากไม่ปฏิบัติตาม } \\
\text { กฎระเบียบของบริษัท หรือกฎหมาย }\end{array}$ & 12 & 8 \\
\hline 13 & $\begin{array}{l}\text { พนักงานใหม่ในที่มงานโครงการยังไม่ทราบระเบียบขั้นตอนการปฏิบัติงาน } \\
\text { (Procedure) ที่เกี่ยวข้องในงาน }\end{array}$ & 12 & 9 \\
\hline 14 & ออกแบบไม่ครบถ้วนทำให้เกิดการแก้ไขงาน (Design Change) ภายหลัง & 12 & 8 \\
\hline 15 & $\begin{array}{l}\text { พนักงานของบริษัทผู้รับเหมาไม่ปฏิบัติตามระเบียบขั้นตอนการปฏิบัติงาน } \\
\text { (Procedure) }\end{array}$ & 12 & 12 \\
\hline 16 & ผู้ขาย (Vendor) ส่งสินค้ามาไม่ตรงกับใบสั่งซื้อ (Purchase Order) & 12 & 9 \\
\hline
\end{tabular}




\section{2. ข้อเสนอแนะ}

1. งานวิจัยนี้ได้ศึกษาถึงประเด็นปัญหาที่มีสาเหตุมาจากการสื่อสารในการบริหารโครงการอีพีซี ซึ่งมีการสำรวจข้อมูล ปัญหาจากการดำเนินงานภายในโครงการอีพีซีของบริษัทกรณีศึกษาเพียงกลุ่มหนึ่งเท่านั้น จึงไม่สามารถบอกถึงปัญหา การสื่อสารที่อาจเกิดขึ้นได้ นอกเหนือจากรายการปัญหาการสื่อสารที่พบในงานวิจัยนี้ ดังนั้นควรมีการติดตามปัญหา การสื่อสารรายการใหม่ที่อาจเกิดขึ้นได้ในอนาคต และต้องทำการปรับเปลี่ยนระบบการสื่อสารให้มีความเหมาะสมต่อ การใช้งานอยู่เสมอ

2. รายละเอียดของระบบการสื่อสารที่พัฒนาขึ้นจะไม่ครอบคลุมถึงการสื่อสารในช่วงของการประกวดราคา (Proposal) กับ ทางบริษัทลูกค้า รวมไปถึงช่วงของการปิดโครงการ (Close out project) เนื่องจากว่างานวิจัยนี้เป็นการวิเคราะห์ของ ปัญหาการผื่อสารที่เกิดขึ้นจากการดำเนินโครงการอีพีซีของบริษัทกรณีศึกษาเท่านั้น ดังนั้นควรมีการศึกษาวิจัยเพิ่มเติม เพื่อให้ระบบการสื่อสารสามารถนำไปใช้งานได้ตั้งแต่ช่วงของการประกวดราคา (Proposal) ไปจนถึงช่วงของการปิด โครงการ (Close out project) ซึ่งจะทำให้ระบบการสื่อสารมีความสมบูรณ์มากยิ่งขึ้น

3. จากหลักการวิจัยดังกล่าว อาจนำไปใช้เป็นแนวทางในการปรับปรุง พัฒนา และกำหนดแผนการสื่อสารของการบริหาร โครงการอีพีซีในธุรกิจจื่นๆได้ อาทิเช่น การก่อสร้างโรงงานอุตสาหกรรม ห้างสรรพสินค้า คอนโดมิเนียม เป็นต้น เนื่องจากการก่อสร้างดังกล่าวล้วนต้องประกอบด้วยงานวิศวกรรม (Engineering) งานจัดซื้อ จัดจ้าง (Procurement) และงานก่อสร้าง (Construction) ทั้งสิ้น ซึ่งรวมไปถึงการดูแลทดสอบการใช้งานของระบบให้เป็นไปตามเงื่อนไขที่ตกลง กันด้วย (Commissioning) ดังนั้นการติดต่อสื่อสาร และการประสานงานที่เกิดขึ้นในการดำเนินโครงการจึงต้อง ประกอบด้วยองค์ประกอบของระบบการสื่อสารที่มีลักษณะเช่นเดียวกับงานวิจัยนี้ 


\section{บรรณานุกรม}

[1] International Standard, "ISO 10006 Quality management systems: Guidelines for quality management in projects," 2003.

[2] บริษัท ปตท. จำกัด (มหาชน). ลักษณะเฉพาะของอุตสาหกรรมปิโตรเคมี [Online]. Available: http://www.pttplc.com/th/Media-Center/Energy-Knowledge/Pages/Petrochemical.aspx, [Accessed: 26 April 2013].

[3] Project Management Institute, "A Guide to Project Management Body of Knowledge (PMBOK)," Fourth Edition. 2008.

[4] ปิยะพงษ์ แก้วหยก, "ปัญหาการติดต่อสื่อสารภายในโครงการก่อสร้าง," วิทยานิพนธ์ปริญญามหาบัณฑิต, สาขาวิชา การจัดการวิศวกรรม คณะวิศวกรรมศาสตร์ มหาวิทยาลัยสยาม, 2552.

[5] นพวรรณ รักฝึกฝน, "การบริหารความเสี่ยงของโครงการออกแบบตกแต่งภายใน," วิทยานิพนธ์ปริญญามหาบัณฑิต, ภาควิชาวิศวกรรมอุตสาหการ คณะวิศวกรรมศาสตร์ จุฬาลงกรณ์มหาวิทยาลัย, 2547.

[6] A. Carbone and D. Tippett, "Project Risk Management Using the Project Risk FMEA," Engineering Management Journal, vol.16 no.4, pp. 28-35, 2004. 